\title{
Responses of International Central Banks to the COVID-19 Crisis
}

Jacob Haas, Christopher I. Neely, and William R. Emmons

This article reviews and explains the recent policy reactions of the Federal Reserve, the European Central Bank, the Bank of England, and the Bank of Japan to the financial and macroeconomic turmoil caused by the COVID-19 pandemic. The financial and monetary policy actions of major central banks in the most recent crisis have, by some metrics, surpassed their responses to the Global Financial Crisis of 2007-09 in both swiftness and scope. (JEL E58, E59, G01, E44, G15)

Federal Reserve Bank of St. Louis Review, Fourth Quarter 2020, 102(4), pp. 339-84.

https://doi.org/10.20955/r.102.339-84

\section{INTRODUCTION}

Concerns about the spread of the COVID-19 virus and its effect on economic activity produced one of the most turbulent periods of financial market activity in history from mid-February to April 2020. In some ways, this episode resembled the events of SeptemberOctober 2008, during the Global Financial Crisis (GFC) of 2007-09. Severe problems arose suddenly in international financial markets. Uncertainty and fear raised volatility and led investors to broadly sell risky assets, which reduced their prices.

International authorities responded to both the GFC and the recent COVID-19-inspired crisis. Fiscal authorities increased spending, including providing much more generous unemployment benefits, while central banks made credit more widely available in financial markets and supported markets for illiquid securities. Regulators allowed banks to reduce their capital and liquidity buffers and encouraged lenders to work with borrowers.

But there are significant differences between the two events, too. The events of September 2008 resembled a bank run. Investors became uncertain about the value of some types of risky housing assets-mortgage-backed securities (MBS) and other asset-backed securities (ABS) not guaranteed by the government and collateralized debt obligations-and therefore sought to reduce their exposure to all such assets and the firms that might own them or have guaranteed them.

Jacob Haas is a research associate, Christopher J. Neely is a vice president and economist, and William R. Emmons is an assistant vice president and economist at the Federal Reserve Bank of St. Louis.

(c) 2020, Federal Reserve Bank of St. Louis. The views expressed in this article are those of the author(s) and do not necessarily reflect the views of the Federal Reserve System, the Board of Governors, or the regional Federal Reserve Banks. Articles may be reprinted, reproduced, published, distributed, displayed, and transmitted in their entirety if copyright notice, author name(s), and full citation are included. Abstracts, synopses, and other derivative works may be made only with prior written permission of the Federal Reserve Bank of St. Louis. 
Fear and uncertainty also drove events in 2020, but this anxiety focused not on opaque financial relationships but on the impact of COVID-19-a true negative supply shock but also a demand shock-on economic activity and employment. 1 For 2020 , the International Monetary Fund (IMF) projects an 8 percent decline in the gross domestic product (GDP) of advanced economies and a 3 percent decline in that for emerging market economies. $\frac{2}{2}$ If this occurs, the COVID-19 recession will be much deeper than the 2007-09 recession, when the GDP of advanced economies declined by 3.3 percent and that for emerging markets economies grew by 2.8 percent (IMF, 2020b).

Policy responses to the two episodes differed because the shocks were fundamentally different. In the COVID-19 crisis, authorities did not immediately seek to broadly stimulate the economy to put people back to work in March-June because some social isolation was necessary to reduce the spread of COVID-19. Instead, authorities concentrated on maintaining the health of the financial system, supporting individuals in isolating themselves but keeping long-term economic relationships intact. In the United States, these policies included Small Business Administration and Federal Reserve (Fed) support for small businesses.

Benefitting from their previous experience, policymakers responded much faster to the incipient COVID-19 crisis than to the GFC of 2007-09. In particular, they introduced new programs and reintroduced old ones more rapidly. The breadth of the policy response was also, in some cases, beyond any previous crisis response. For example, the introduction of direct Fed lending to businesses, states, and cities in the COVID-19 crisis is unprecedented in the United States, as is the likely eventual size of the Fed's balance sheet (Timiraos and Hilsenrath, 2020). In a departure from the previous episode, all major central banks felt themselves to be in broadly similar situations. At the start of the GFC, in 2007 to 2008, leaders of the European Central Bank (ECB) and the Bank of Japan (BOJ) thought their economies were somewhat insulated and that the financial crisis was mostly a problem for the United States and United Kingdom. In 2020, the crisis was truly global from the outset.

This article examines how the major central banks-the Fed, the ECB, BOJ, and the Bank of England (BOE) - responded to the financial market turbulence of February-April 2020 and the anticipated plunge in economic activity. We summarize how and why these central banks implemented credit, asset-purchase, and banking support programs and compare and contrast the international policy responses. While future developments may overshadow those we document here, we hope this article will be useful to future readers who wish to understand the policy responses as they were rolled out in the early months of the COVID-19 crisis. We also touch briefly on fiscal and regulatory responses, particularly their interactions with central bank policies.

The next section of the article discusses central bank financial market and regulatory policies, while Section 3 describes the recent COVID-19 financial turmoil that contributed to an unprecedented economic downturn. Section 4 details the policy responses of the four major central banks and compares their efforts. Section 5 draws conclusions. 


\section{POLICY TOOLS FOR FINANCIAL TURMOIL AND RECESSIONS}

The three macroeconomic tools are monetary, fiscal, and financial policies. We briefly review the separate use of these tools by central banks before considering their interaction in specific episodes. In doing so, we often refer specifically to the Fed's tools. Other central banks possess similar tools.

\subsection{Monetary Policy}

Former Federal Reserve Chair Ben Bernanke (2012b) described a central bank's main policy tools as monetary policy and lender-of-last-resort powers. Both types provide credit to the private sector. There is no bright line between the policies, but lender-of-last-resort actions tend to be narrowly focused and short-lived, while monetary policy has broader and longer-lasting impacts.

Central banks conduct monetary policy to stabilize the economy-that is, to decrease fluctuations in economic activity. When short-term interest rates are positive, central banks in developed economies typically conduct monetary policy by adjusting short-term interest rates to influence broad financial conditions, including longer-term interest rates, monetary and credit aggregates, other asset prices, volatility, risk premia, and liquidity. The Fed, for example, normally uses open market operations to maintain an overnight interbank interest rate-the federal funds rate-within a target range that it deems appropriate for economic conditions.. By influencing asset prices, central banks can affect consumption, investment, production, employment, and inflation.

When short-term interest rates neared the zero lower bound in 2008, central banks, including the Fed, employed unconventional monetary policy tools on a previously untested scale. $\underline{4}$ These tools consisted of large-scale asset purchases (also called quantitative easing [QE]) and forward guidance-communications by central bank leaders of their views about the economy and how their policy tools were likely to evolve over time. ${ }^{5}$ Such tools can be used to influence the broader economy through changes in asset prices, just as short-term interest rates can. To combat the GFC, in 2007-09, central banks expanded their toolkits beyond previous limits and laid the groundwork for many recent policy measures.

Surveying the literature evaluating the international use of new monetary tools, Bhattarai and Neely (forthcoming) find that a variety of types of studies provide strong evidence that broad central bank asset purchases moved domestic asset prices and spilled over to move international prices, while narrow asset purchase programs (in a particular market) and bank lending support programs normalized market functioning and facilitated intermediation. In addition, central banks learned about the degree to which it was possible to impose modestly negative interest rates. $\underline{6}$ Central bankers also generally consider that such unconventional programs substantially improved financial conditions, raising growth and avoiding deflation (Bhattarai and Neely, forthcoming).

\subsection{Fiscal Policy}

Government spending and/or taxes constitute fiscal policy. Fiscal actions that change the current budget balance (i.e., increase or decrease the budget deficit) may affect the economy, 


\section{Abbreviations}

ABS: asset-backed securities (not guaranteed by the federal government)

APF: Asset Purchase Facility

APP: Asset Purchase Programme

BOE: Bank of England

BOJ: Bank of Japan

bp: basis points

CCFF: Covid Corporate Financing Facility

CP: commercial paper

CPFF: Commercial Paper Funding Facility

ECB: European Central Bank

ESF: Exchange Stabilization Fund

ETF: exchange-traded fund

EUREP: Eurosystem Repo Facility for Central Banks

Fed: Federal Reserve

FG: forward guidance

FIMA: foreign and international monetary authorities

FOMC: Federal Open Market Committee

GFC: Global Financial Crisis of 2007-09

GSFF: Growth-Supporting Funding Facility

IMF: International Monetary Fund

JGB: Japanese government bond

JGS: Japanese government security

J-REIT: Japanese Real Estate Investment Trust

LOLR: lender of last resort
LSAP: large-scale asset purchases

LTRO/TLTRO/PELTRO: (targeted/pandemic) longer-term refinancing operations

MBS: mortgage-backed securities (issued by Fannie Mae and Freddie Mac, government-sponsored enterprises)

MLF: Municipal Liquidity Facility

MMLF: Money Market Mutual Fund Liquidity Facility

MRO: main refinancing operations

MSLP: Main Street Lending Program

OAS: option-adjusted spread

OIS: overnight index swap

PDCF: Primary Dealer Credit Facility

PEPP: Pandemic Emergency Purchase Programme

PMCCF/SMCCF: Primary/Secondary Market Corporate Credit Facilities

PPPLF: Paycheck Protection Program Liquidity Facility

PSPP: Public Sector Purchase Programme

QE: quantitative easing

SBLF: Stimulating Bank Lending Facility

SMEs: small and medium-sized enterprises

SPV: special purpose vehicle

T-bill: Treasury discount bill

TALF: Term Asset-Backed Securities Loan Facility

TBA: to be announced

TFS/TFSME: Term Funding Scheme/TFS with additional incentives for SMEs

WHO: World Health Organization

but it is difficult to predict and measure this effect. ${ }^{7}$ Balanced-budget fiscal policy measuresthat is, equal increases in spending and tax revenues-are likely to have smaller effects.

Central banks can change the cost of government debt or even the ability of governments to borrow. Central bank purchases of government debt are said to monetize that debt because the central bank creates money to pay for the government debt it retires. Monetization becomes a problem if it is perceived to remove a constraint on government spending and make the debt unsustainable in the longer run.

Another way that central banks may affect fiscal policy is via credit allocation. A central bank purchase of MBS, for example, reduces credit costs for mortgage borrowers relative to other types of borrowers. Similarly, central bank lending to small businesses or purchases of corporate or municipal securities benefit particular borrowers. These are transfers of value to particular agents and therefore are fiscal policy. 


\subsection{Financial Policy}

Government or central bank financial policies can affect individual financial institutions or markets or infrastructure (i.e., trading venues, information networks, and payments and settlement systems) without necessarily affecting broad financial conditions. These policy actions include the following:

- discount window lending: short-term collateralized loans to individual depository institutions $\underline{\underline{8}}$;

- emergency lending under Federal Reserve Act Section 13(3) authority as amended in the Dodd-Frank Act: creation and operation of funding, credit, liquidity and loan facilities that are available to a broad set of counterparties ${ }^{9}$; and

- supervision and regulation of financial institutions. $\underline{10}$

When central banks engage in discount window lending or create specialized credit facilities, they act as lenders of last resort to particular institutions or markets. As the name suggests, a lender of last resort provides short-term loans to banks when private lending is unavailable on reasonable terms.

Walter Bagehot (1873) prescribed similar central bank lending practices in Lombard Street: During a panic, central banks should lend freely against good assets at a high interest rate. $\underline{11}$ Bernanke (2012a) argues that lender-of-last-resort powers are the primary tool a central bank has to maintain or restore financial stability and that Bagehot's dictum on their use remains valid today. $\frac{12}{}$

Interventions targeted at particular financial institutions, markets, or utilities may change broad financial conditions. For example, substantial emergency lending could influence interest rates in other sectors, creating a monetary policy action. If that is not intended, the central bank could sterilize (i.e., neutralize) the wider impact of the emergency lending through offsetting open market operations. For example, if a central bank provided $\$ 100$ billion to some sector in a special lending program, it could neutralize the action's broader monetary policy effects by selling $\$ 100$ billion of Treasury securities in open market operations.

In the United States, the Department of the Treasury typically coordinates and backstops unusual Fed lending, that is, non-discount-window lending, because loan losses are transfers of value to debtors. That is a fiscal-policy action and, therefore, should be decided by Congress.

\subsection{A Two-Front War: The Economy and the Financial System}

Severe financial crises are rare in U.S. history but have occurred more frequently in other countries (Reinhart and Rogoff, 2009). A nationwide banking panic in 1931-33 extended and deepened the Great Depression. A severe financial meltdown in 2008 likewise turned a mild, incipient downturn into the Great Recession. $\frac{13}{}$ The current U.S. recession began in March 2020, the same month severe financial turmoil emerged (National Bureau of Economic Research, 2020).

Although recessions can occur in the absence of a financial crisis, the real economy and the financial sector are interdependent. Concern about the real economy can produce volatility that inhibits financial activity, which feeds back to the real economy. Such cycles challenge 


\section{Did Post-2008 Financial Reforms Reduce Financial Crisis Risk?}

President Obama signed the Dodd-Frank Wall Street Reform and Consumer Protection Act into law on July 21,2010 . The act is a complex piece of legislation, consisting of 16 separate sections (see table). The preamble to the act states its purposes:

- to promote the financial stability of the United States by improving accountability and transparency in the financial system,

- to end "too big to fail,"

- to protect the American taxpayer by ending bailouts,

- to protect consumers from abusive financial services practices, and

- for other purposes.

Although many Dodd-Frank provisions were designed to address shortcomings in the financial system demonstrated by the GFC of 2007-09, the overall structure of the law closely followed a proposal laid out in March 2008 by Barack Obama (2008) in a campaign speech in New York. Obama identified these objectives for financial reform:

- expand the Fed's authority to supervise systemically important financial institutions;

- stiffen existing capital and liquidity rules;

- consolidate the regulatory structure;

- practice functional, rather than institutional, regulation;

- crack down on trading abuses; and

- identify and address systemic risks.

Arguably, the Dodd-Frank Act realized these objectives, with the exception of consolidating the regulatory structure.* Perhaps as a result of some of the changes arising from the act, such as higher bank capital requirements and more disclosure about financial market activity, banks and the broader financial system have remained strong in the early stages of the current recession. As we describe in greater detail in the article, however, some of this resilience also is due to timely large-scale interventions by the Fed and Treasury to preempt emerging credit-market dysfunction in March 2020.

*Although the Office of Thrift Supervision was eliminated, with its authorities and responsibilities transferred primarily to the Office of the Comptroller of the Currency, two new financial regulatory agencies were created: the Bureau of Consumer Financial Protection and the Office of Financial Research. Moreover, the Dodd-Frank Act established the Financial Stability Oversight Council as a framework to bring together existing financial regulators to monitor and address financial-stability risks. 


\section{Dodd-Frank Act: Titles and Major Provisions}

\begin{tabular}{|c|c|c|}
\hline Title & Purpose & Major provisions \\
\hline \multirow{4}{*}{ I } & \multirow{4}{*}{ Financial stability } & $\begin{array}{l}\text { - Creates the Financial Stability Oversight Council and the Office of } \\
\text { Financial Research. }\end{array}$ \\
\hline & & - Increases Fed oversight of nonbank financial institutions. \\
\hline & & $\begin{array}{l}\text { - Creates Collins Amendment (Section 171) requiring higher bank } \\
\text { capital levels. }\end{array}$ \\
\hline & & - Requires banks to establish "living wills." \\
\hline II & Orderly liquidation authority & $\begin{array}{l}\text {-The Federal Deposit Insurance Corporation (FDIC) gains non-bank } \\
\text { resolution authority. }\end{array}$ \\
\hline \multirow[b]{2}{*}{ III } & \multirow{2}{*}{$\begin{array}{l}\text { Transfer of powers to the Comptroller of the Currency, } \\
\text { the FDIC, and the Board of Governors }\end{array}$} & • Abolishes the Office of Thrift Supervision (OTS). \\
\hline & & $\begin{array}{l}\text { - Transfers OTS powers to the Comptroller of the Currency, the FDIC, } \\
\text { and the Board of Governors. }\end{array}$ \\
\hline IV & Regulation of advisers to hedge funds and others & $\begin{array}{l}\text { - Clarifies requirements for covered investment advisers to provide } \\
\text { information to the Securities and Exchange Commission and the FDIC. }\end{array}$ \\
\hline V & Insurance & $\begin{array}{l}\text { - Establishes a Federal Insurance Office within the Department of } \\
\text { the Treasury. }\end{array}$ \\
\hline $\mathrm{VI}$ & Improvements to regulation of depository institutions & $\begin{array}{l}\text { - Closes loopholes such as the use of industrial loan companies. } \\
\text { - Volcker Rule (Section 619) restricts proprietary trading by banks. }\end{array}$ \\
\hline VII & Wall Street transparency and accountability & - Reforms over-the-counter derivatives regulation. \\
\hline VII & Payment, clearing, and settlement supervision & $\begin{array}{l}\text { - Designates certain market utilities as systemically important and } \\
\text { subject to supervision. }\end{array}$ \\
\hline IX & $\begin{array}{l}\text { Investor protections and improvements to the regula- } \\
\text { tion of securities }\end{array}$ & $\begin{array}{l}\text { - Requires risk retention by originating institutions of ABS. } \\
\text { - Clarifies the liability of rating agencies. }\end{array}$ \\
\hline \multirow[b]{2}{*}{$\mathrm{X}$} & \multirow[b]{2}{*}{ Bureau of Consumer Financial Protection } & - Creates the Bureau of Consumer Financial Protection \\
\hline & & $\begin{array}{l}\text { - Consolidates from other federal agencies and extends existing } \\
\text { consumer financial-protection powers. }\end{array}$ \\
\hline $\mathrm{XI}$ & Federal Reserve System provisions & $\begin{array}{l}\text { - Establishes limits on the use by the Board of Governors of its } \\
\text { Section 13(3) authority under the Federal Reserve Act. }\end{array}$ \\
\hline XII & Improving access to mainstream financial institutions & - Encourages alternatives to payday loans. \\
\hline XIII & Pay It Back Act & - Establishes procedures to wind down the TARP. \\
\hline \multirow[b]{2}{*}{ XIV } & \multirow[b]{2}{*}{ Mortgage Reform and Anti-Predatory Lending Act } & - Prohibits yield-spread payments to mortgage originators. \\
\hline & & $\begin{array}{l}\text {-Establishes new rules on high-cost mortgages, appraisals, servicing, } \\
\text { and modifications. }\end{array}$ \\
\hline $\mathrm{XV}$ & Miscellaneous provisions & - Restricts trade in "conflict minerals." \\
\hline $\mathrm{XVI}$ & Section 1256 contracts & $\begin{array}{l}\text { - Tightens the definitions of tax reporting of gains and losses from } \\
\text { mark-to-market adjustments and straddles. }\end{array}$ \\
\hline
\end{tabular}

SOURCE: H.R. 4173 (111th Congress): Dodd-Frank Wall Street Reform and Consumer Protection Act; https://www.govtrack.us/congress/bills/111/ hr4173/text. 


\section{Central Bank Responses and the "Greenspan Put"}

Market observers commonly criticize central banks for responding to financial market turmoil with monetary policy easing that often arrests falling asset prices, particularly stock prices. The idea that the Fed-or central banks more generally-prevented or tried to prevent stock market losses became popular in the 1990s, when the supposed guarantee against losses was christened the "Greenspan Put," after then-Chair of the Fed, Alan Greenspan.* Miller, Weller, and Zhang (2002) argue that exaggerated faith in the Fed's power to prevent downside risk raised the value of U.S. stocks above that implied by dividends.

Central bankers, however, would deny that they are trying to prevent stock price declines or peg stock prices to some level. Rather, their interventions seek to alleviate extreme stress and ensure continued market functioning (Schnabel, 2020). In the words of Chair Powell (2020b), "We're not trying to move markets to a particular level. We just want them to work."

*The term "put" refers to a type of derivative security intended to reduce the potential of large losses on an asset. An American put option on a given asset gives the holder the right, but not the obligation, to sell the given asset at a pre-specified price, that is, the strike price, on or before a specified date. The payoff to such an option is the difference between the strike price and the price when the option is exercised. Thus, a put option on a given asset hedges the risk of a substantial decline in the asset price because the put becomes more valuable as the asset price falls.

economic policymakers who must use monetary and fiscal policy to combat recession but a different set of tools to keep the financial system functioning.

Uncertainty about economic events can produce "financial accelerator" effects through its effect on asset prices. Falling asset prices reduce a firm's creditworthiness by lowering the net worth of the firm's owners and the value of collateral it can pledge to lenders. $\stackrel{14}{ }$ Owners with little equity value have an incentive to borrow money to take risky but potentially profitable actions, because the owners keep any gains but cannot lose more than their (small) equity stake in the firm. Lenders are reluctant to lend to such firms (Bernanke and Gertler, 1989, and Calomiris and Hubbard, 1990). Such a sudden retraction of credit or increase in its cost can disrupt the operation of financial firms, such as specialists on Wall Street and some hedge funds, that borrow most of their operating funds. $\frac{15}{}$ The potential for bankruptcy or disruption of credit for some financial firms jeopardizes the complex system of payments that links all financial institutions. $\frac{16}{}$ A loan default by a bankrupt firm might render the firm's creditors insolvent as well, for example.

Disruption to financial market functioning can exacerbate recessions by inhibiting intermediation, that is, credit for investment and trade (Schularick and Taylor, 2012). A large falloff in business investment is virtually synonymous with recession in U.S. data. $\frac{17}{}$ While disruptions of other industries can be contained, preserving the financial system is crucially important to the broader economy because credit, payments mechanisms, and settlement systems underpin virtually all transactions. Their importance is most evident when they are disrupted, as in September 2008 and March 2020. Despite severe shocks in March, a full-blown financial crisis has not yet resulted. $\stackrel{18}{ }$ Nonetheless, history may judge that only aggressive central bank interventions prevented this outcome. The Fed rolled out many distinct financial interventions within weeks, several of which were reincarnations from the 2007-09 crisis (see Table 1A). Congress backed these Fed actions by appropriating $\$ 454$ billion of U.S. Treasury funds to absorb the possibly substantial risk involved. Such actions have often prompted accusations that central banks try to prop up asset prices, protecting stockholders from losses. The shaded insert "Central Bank Responses and the 'Greenspan Put" discusses this issue. 


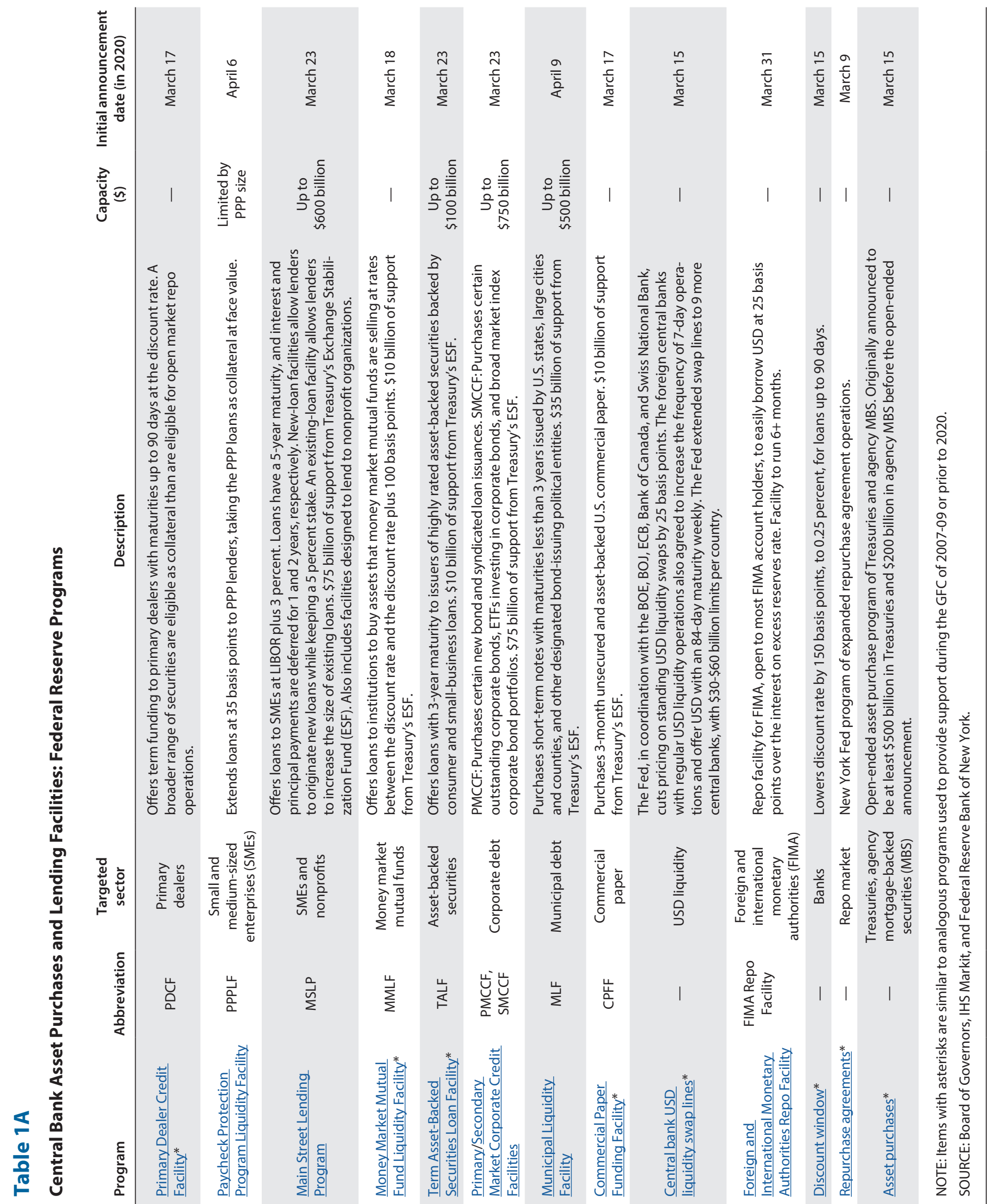




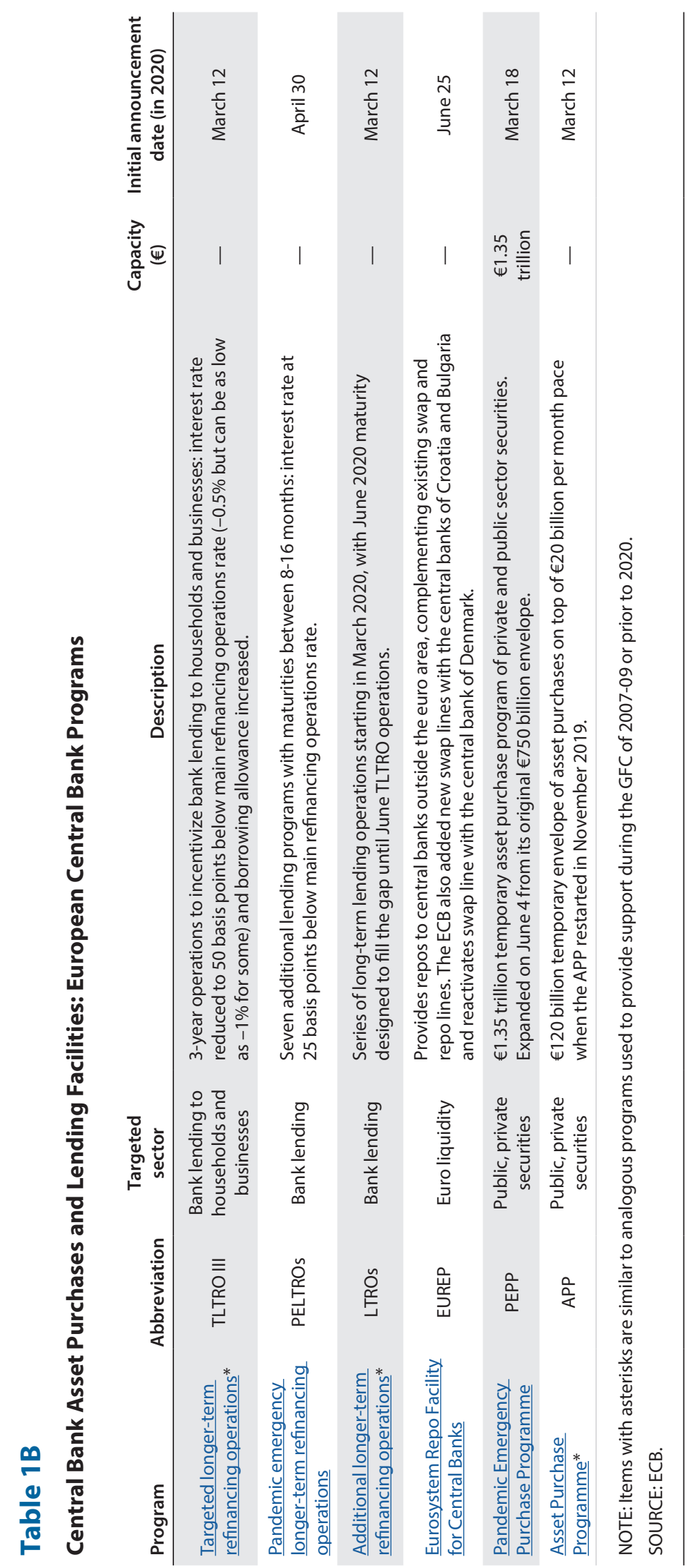




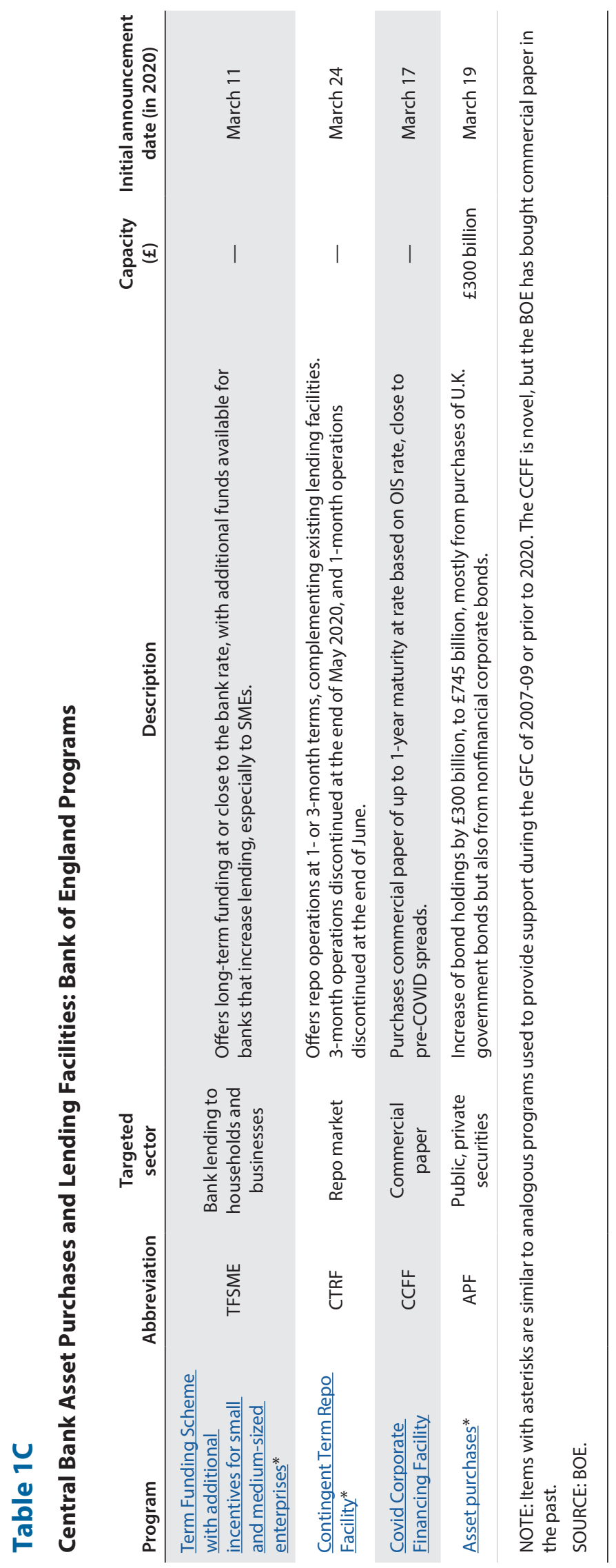




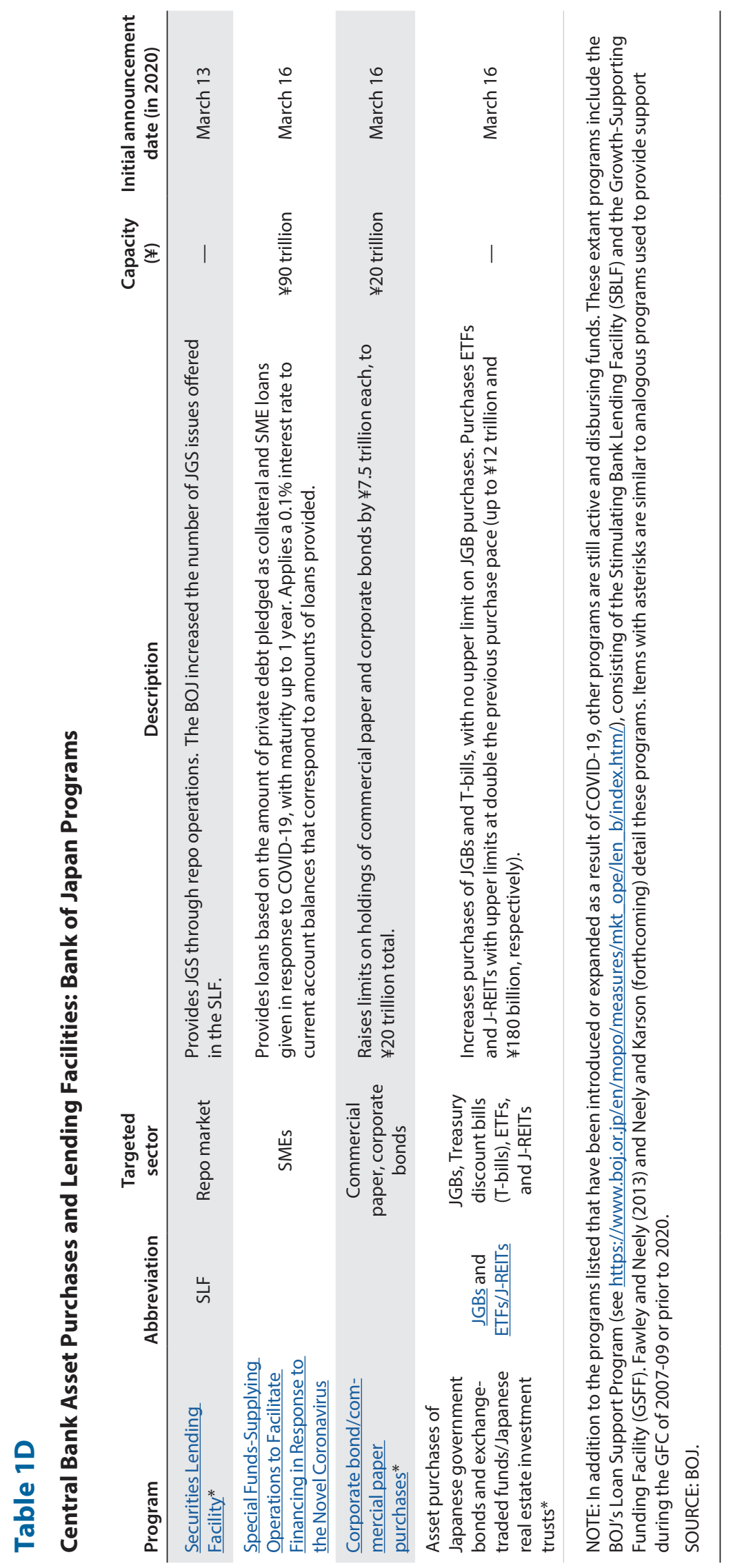




\section{THE COVID-19 FINANCIAL TURMOIL}

This section first briefly discusses the spread of COVID-19 before reviewing the causes and symptoms of the recent COVID-19-related financial turmoil of February-April 2020.

\subsection{The Global Spread of COVID-19}

The first cases of COVID-19 were reported in December 2019 in Wuhan, China. The World Health Organization's (WHO's) Chinese Office learned of a media statement on the website of the Wuhan Municipal Health Commission on local cases of "viral pneumonia" (Ma, 2020). In the following weeks, the new virus spread to Thailand, Japan, South Korea, the United States, and France. The Chinese government locked down Wuhan and most of Hubei Province in late January 2020, halting outbound travel and public transit. By the end of January there were almost 10,000 confirmed cases of COVID-19 in 19 countries and over 200 deaths (WHO, 2020b).

Countries began implementing travel restrictions and lockdown measures as confirmed cases began to jump in the following weeks. On January 31, the United States suspended travel by foreign nationals from China, then in mid-March likewise suspended travel by foreign nationals from Europe. In late February, Italy locked down its hardest hit towns in the Lombardy region and then moved to a country-wide lockdown by March 9: schools and nonessential businesses were closed (Taylor, 2020). By the end of March, well over 100 countries had instituted a lockdown, and there were almost 800,000 confirmed cases and 40,000 deaths worldwide (BBC, 2020, and WHO, 2020a). The virus continued to spread through the spring and summer of 2020. Some areas saw lower caseload growth and mortality rates and were able to ease some of their lockdown measures, while other regions continued to struggle to contain the spread of the virus.

The loss of life and uncertainty of safety surrounding the pandemic took a devastating human toll but also greatly affected the global economy. Consumers were unable or unwilling to purchase goods and services, and the closure of non-essential businesses, suspension of schools, slowdown of travel and tourism, and cancellation of large public events caused by lockdowns all had major implications on economic activity and employment. As of July 2, 2020, there were over 10 million confirmed cases and 500,000 deaths as a result of COVID-19 (WHO, 2020c).

\subsection{The Financial Market Turmoil}

Financial crises are periods in which expectations of asset values or economic activity are suddenly revised in ways that dramatically change asset prices and threaten the stability of the economic system through asset price volatility and disrupted financial activity.

The spread of COVID-19 prompted fears of disruptions to supply chains and the labor force that would curtail economic activity and bring on a severe recession. Such fears prompted many investors to sell risky assets, such as high-yield corporate bonds, in favor of safer assets, such as Treasury securities. Prices of many risky assets fell, while volatility, trading volume, and bid-ask spreads rose. That is, there was a flight to safety. Yields on very safe 10-year 


\section{Figure 1}

\section{Corporate Bond, Mortgage, and Sovereign Spreads}

\section{A. U.S. corporate bond and mortgage spreads}

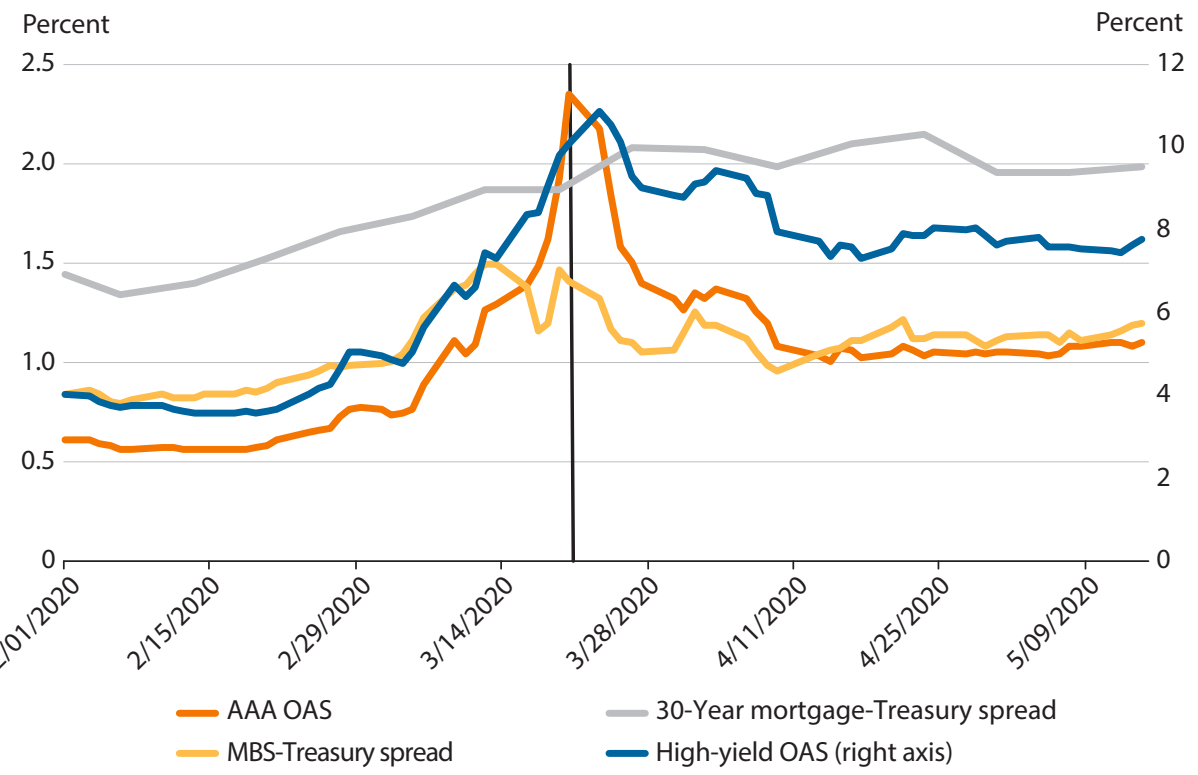

\section{B. Sovereign spreads}

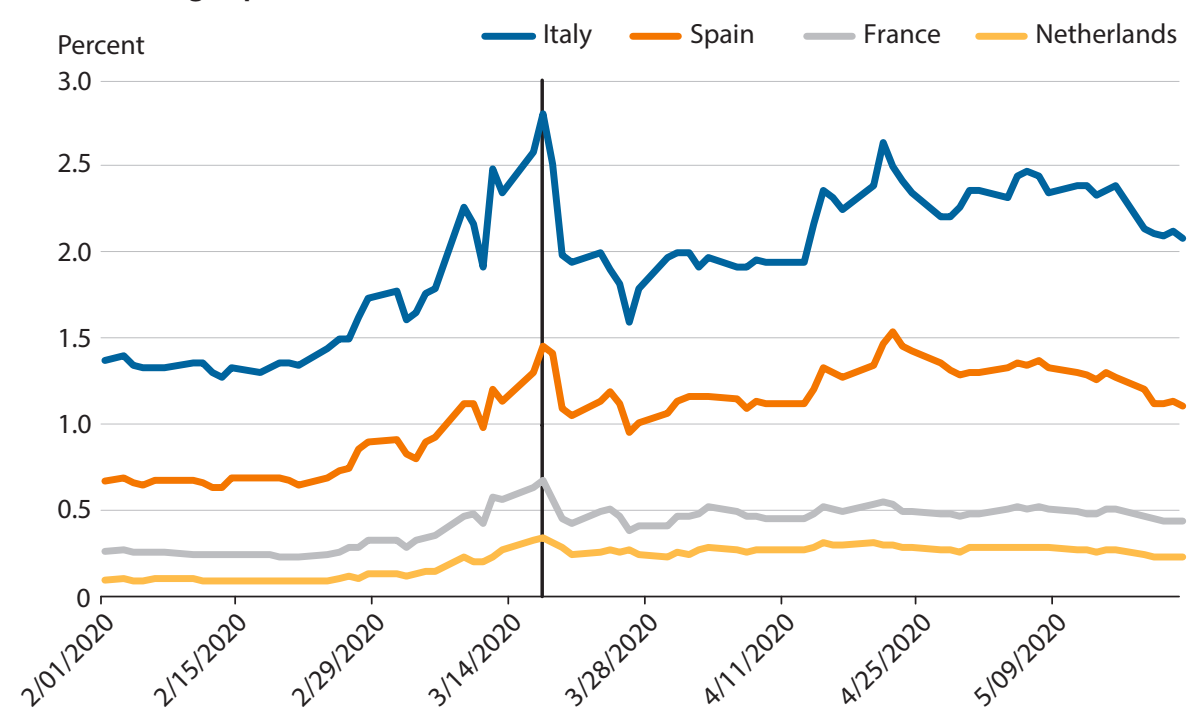

NOTE: Panel A shows the ICE BofA (Bank of America) AAA U.S. Corporate Index Option-Adjusted Spread (AAA OAS); the ICE BofA FNMA Current Coupon Effective Yield less the 10-year Treasury yield (MBS-Treasury spread); the 30-year mortgage-Treasury spread, which is the 30-year fixed mortgage rate less the 30-year constant-maturity Treasury yield; and the ICE BofA U.S. High Yield Option-Adjusted Spread (High-yield OAS). The vertical line in Panel A indicates the announcements of the PMCCF/SMCCF on March 23, 2020. Panel B shows 10-year sovereign yield spreads versus German bonds. The vertical line in Panel B indicates the announcement of the PEPP on March 18, 2020.

SOURCE: FRED ${ }^{\circledR}$, Federal Reserve Bank of St. Louis; Haver Analytics; and ICE/Bank of America Merrill Lynch. 
Treasuries fell from 1.88 percent in January 2020 to a historic low of 0.54 percent on March 9 , and they remained near that level through May. Panel A of Figure 1 shows the rise in risk spreads over Treasury yields. The spread over Treasury securities of government-guaranteed MBS, a default-risk-free security, rose from late February to early March, reflecting heightened interest rate and liquidity risks (Mizrach and Neely 2020a,b,c,d,e). A selloff in high-yield grade (i.e., fairly risky) debt boosted the spreads of those securities to about 11 percent on March 23, in contrast to the 3 to 4 percent range common in early February 2020. Conditions briefly resembled those of September-October 2008 (Fawley and Neely, 2013).

Panel A of Figure 1 shows that most U.S. risk spreads peaked the week of March 16-23. The events of this week merit special explanation. The Federal Open Market Committee (FOMC) had lowered the federal funds target range by 50 basis points at an unscheduled meeting on March 3, but increasing financial market stress prompted repeated credit provision through repurchase agreements (repos) the week of March 9-14. Although the FOMC had a meeting scheduled for March 17-18, financial market dislocation prompted the committee to meet early, on the morning of Sunday, March 15, to be able to announce their plans prior to the opening of Asian markets in the U.S. evening. The FOMC announced purchases of at least $\$ 700$ billion in Treasuries and MBS, although it would not classify those purchases as open ended until the end of that week. On the same day, six central banks-the Fed, the Bank of Canada, the BOE, the BOJ, the ECB, and the Swiss National Bank-announced new foreign exchange swap arrangements to provide liquidity in U.S. dollars (USD) internationally.

Despite these expansionary moves, however, international stock prices fell sharply-the Dow dropped nearly 3,000 points-on the morning of Monday, March 16 and circuit breakers halted trading in several markets. As discussed previously, falling asset prices reduce the net worth of the firms and individuals that own them, making them less creditworthy borrowers and discouraging lending.

It is not clear exactly how to interpret this negative stock market reaction. Markets may have seen the FOMC announcement as disappointingly timid or as an indication of surprisingly bad economic news. President Trump's warnings on that Monday of a prolonged shutdown might have exacerbated the stock market reaction.

From March 16 to 23, however, the Fed would release plans for several new lending facilities to stabilize financial markets and make the previously announced asset purchases open ended. These facilities included the Primary Dealer Credit Facility (the PDCF), the Commercial Paper Funding Facility (CPFF), the Money Market Mutual Fund Liquidity Facility (MMLF), the Main Street Lending Program (MSLP), the Term Asset-Backed Securities Loan Facility (TALF), and the Primary and Secondary Market Corporate Credit Facilities (PMCCF and SMCCF). This combination of efforts seemed to stabilize markets in the latter part of March and April.

In Europe, the flight to safety took the form of rising sovereign yields for all countries, including Germany-whose bond yields serve as the low-risk benchmark-and a widening of yield spreads between high-risk countries, such as Italy, and Germany. Panel B of Figure 1 shows the widening of spreads versus Germany in early March, until the announcement of the Pandemic Emergency Purchase Programme (PEPP) on March 18, which is indicated by 
Figure 2

\section{LIBOR-OIS Spreads}

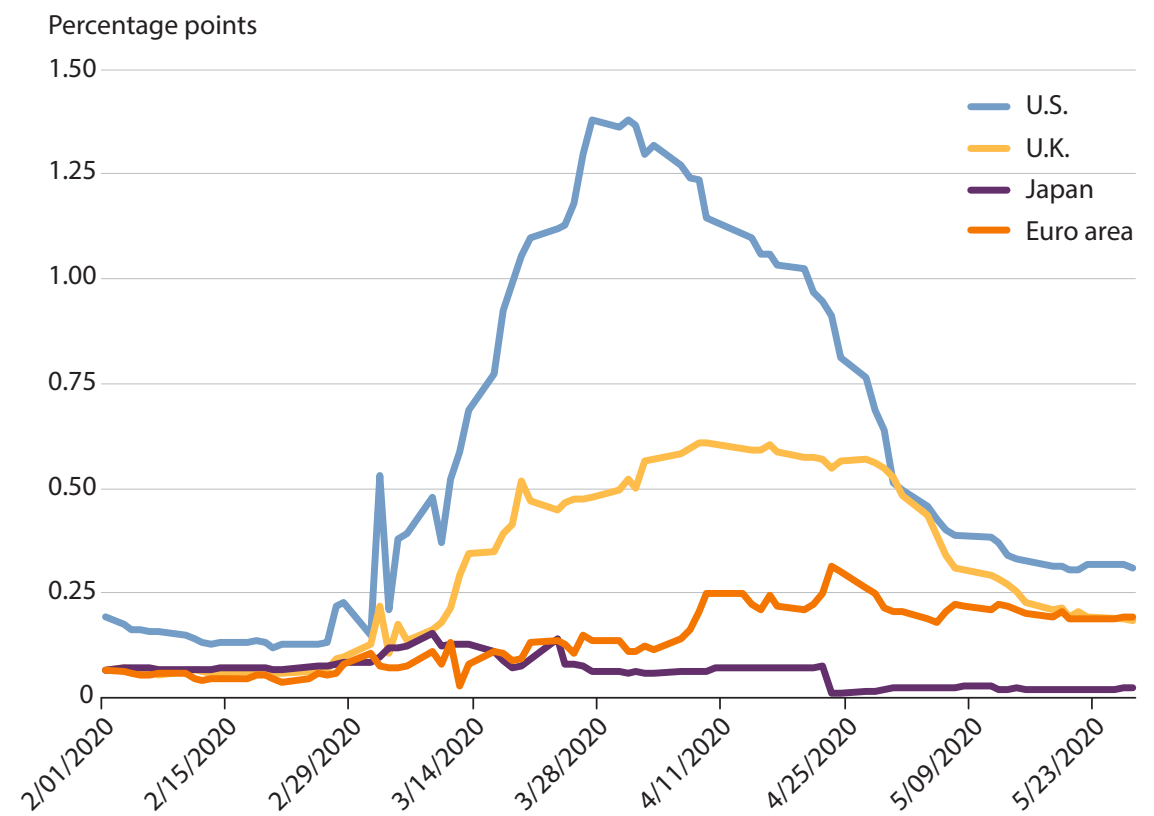

NOTE: The figure shows 3-month interbank lending rates less 3-month same-currency OIS rates for the USD LIBOR rate (U.S.), the British pound LIBOR rate (U.K.), the Tokyo Interbank Offered Rate (TIBOR) for the yen (Japan), and the euro-denominated Euro Interbank Offered Rate (EURIBOR) (euro area).

SOURCE: Haver Analytics, ICE, Refinitiv, and Tullett Prebon.

the vertical line. Differences in spread behavior largely reflected the perceived risk of default, which was likely higher for countries with high debt-to-GDP ratios and small size. According to 2018 OECD data, the debt-to-GDP ratios of Italy, Spain, France, the Netherlands, and Germany were 147 percent, 115 percent, 122 percent, 66 percent, and 70 percent, respectively. .19

The 3-month LIBOR-OIS spread is a popular measure of money market stress, as it measures the willingness of banks to make unsecured loans. ${ }^{20}$ Figure 2 shows that the 3 -month LIBOROIS spread started increasing in early March for the monetary areas of each of the major central banks discussed here. It increased more in the United States and United Kingdom than in the euro area and Japan, indicating that investors might have perceived a greater risk of default by a U.S. or U.K. bank than one in the euro area or Japan. Alternatively, it might have reflected lower expectations of a government rescue of a defaulting bank in the United States or United Kingdom. The U.S. LIBOR-OIS spread was particularly high for the week of March 16-23, which was a particularly difficult week on U.S. financial markets, as discussed previously.

From mid-February to late March, stock prices fell rapidly from fairly high values after a 10-year bull market (Mizrach and Neely, 2020c). Figure 3 illustrates parallel declines in the prices of the S\&P 500, Japanese Nikkei 225, German Dax, and U.K. FTSE All-Share indices. Implied volatility, as measured by the VIX (a forward-looking measure of volatility derived 
Figure 3

\section{Stock Market Responses}

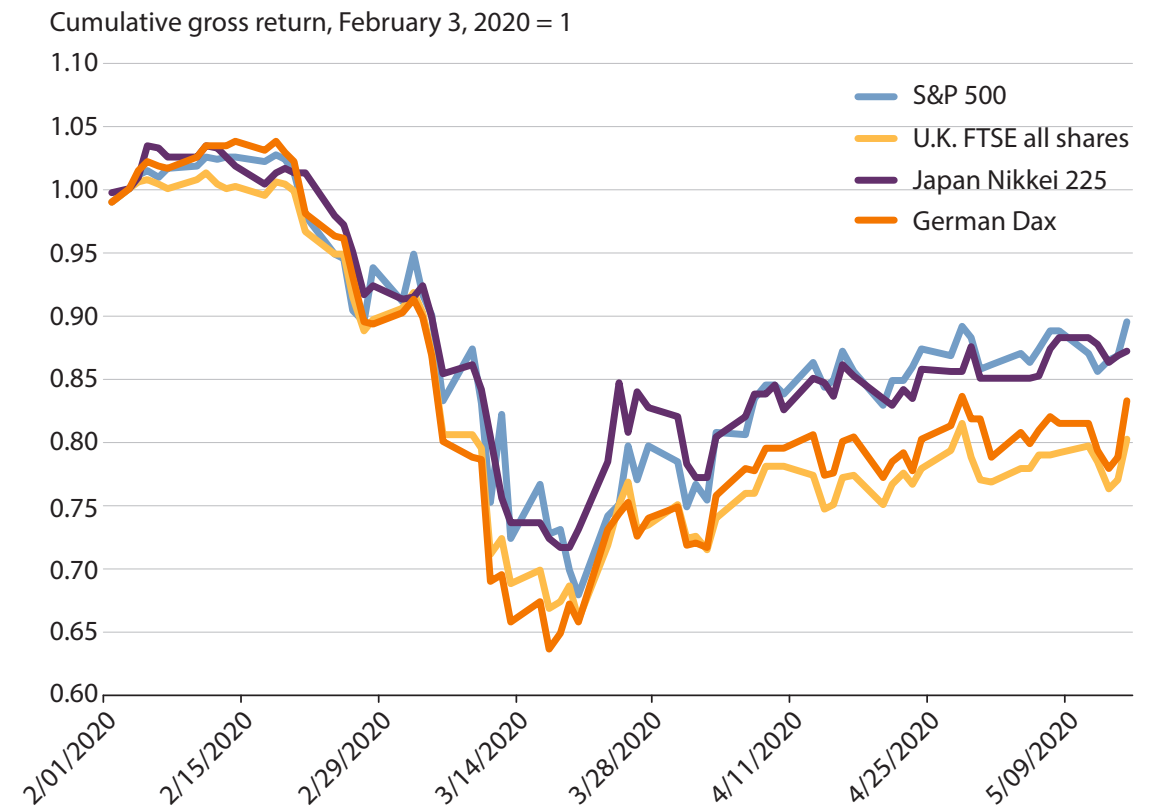

NOTE: The figure illustrates movements in international stock indices. The values are indexed to equal 1 on February 3, 2020. SOURCE: Deutsche Bourse, Financial Times, Haver Analytics, New York Times, and Standard \& Poor's.

from options prices), started rising sharply on about February 19 and peaked on March 16 before declining to lower-but still historically high-levels (Panel A of Figure 4). This pattern is consistent with the negative correlation historically observed between uncertainty and stock returns. Increased uncertainly is also consistent with the sharp increase in equity market bidask spreads shown in Panel B of Figure 4. Market makers widen their quoted spreads in fast moving, uncertain markets to avoid taking losses to more-informed traders. Equity trading volume (not shown in the figure) began rising on February 20, peaked on February 28, but remained elevated through March (Mizrach and Neely, 2020c).

The flight to safety included a shift to relatively safe USD assets that appreciated the tradeweighted USD by 8 percent from late February to March 23 (Panel A of Figure 5). Such appreciation often occurs in times of crisis. Panel B of Figure 5 shows that the trade-weighted USD also rose after the September 11, 2001, attacks and in September 2008. $\underline{21}$ As in other markets, bid-ask spreads widened and foreign exchange trading volume rose, reaching 540 billion USD per day on FXall, the most active interdealer trading network (Mizrach and Neely, 2020b).

Although recessions and (particularly) financial crises are sudden by nature, the real effects of the current downturn appeared unusually suddenly and with great severity. $\underline{22}$ Weekly U.S. initial unemployment insurance claims surged from 282,000 on March 14 to 3.3 million on March 21 to a completely unprecedented 6.9 million on March 28 (Figure 6). The downturn was not evenly spread out across sectors: The leisure and hospitality and health sectors were 


\section{Figure 4}

\section{Financial Market Volatility}

\section{A. Stock index and Treasury note futures volatility}

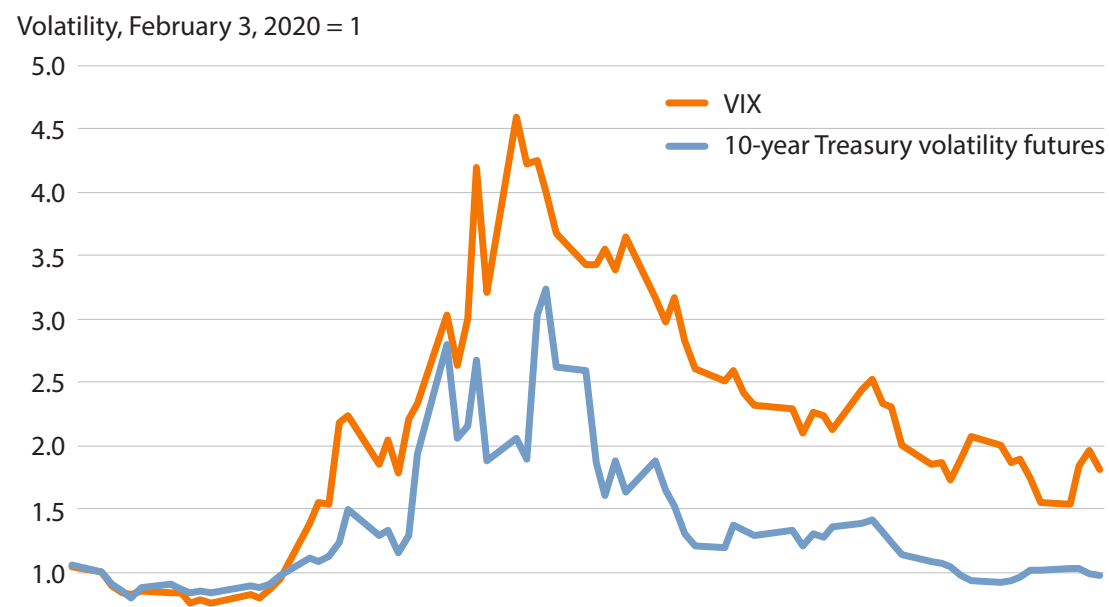

0.5

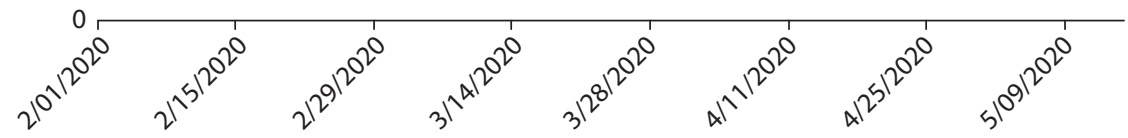

\section{B. Bid-ask spreads for individual stocks}

Bid-ask spread, February 3, $2020=1$

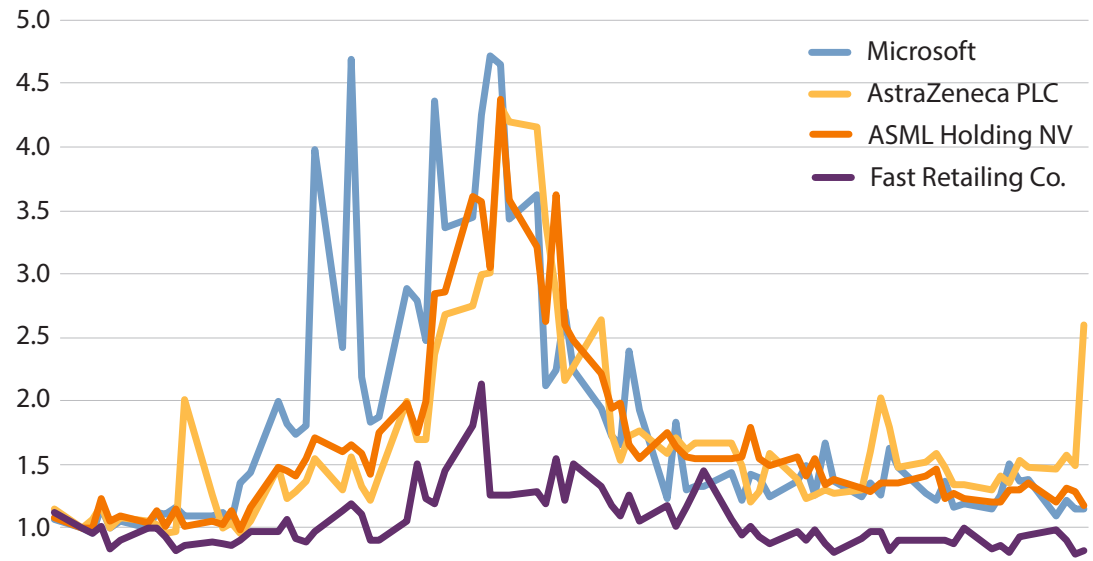

0.5

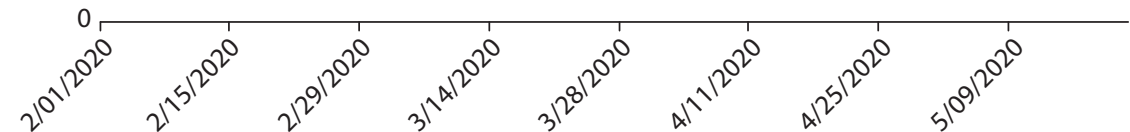

NOTE: Panel A shows two forward-looking measures of financial market volatility obtained from options markets: the VIX and the volatility index on 10-year Treasury futures contracts. For ease of comparison, the volatility indices are indexed to their values on February 3, 2020. Panel B shows bid-ask spreads for the companies that make up the largest portion of the S\&P 500, FTSE 100, Euro Stoxx 50, and Nikkei 225, respectively, as of July 2020.

SOURCE: Bloomberg and FRED ${ }^{\oplus}$, Federal Reserve Bank of St. Louis. 
Haas, Neely, Emmons

\section{Figure 5}

\section{The Foreign Exchange Value of the USD}

\section{A. Normalized foreign exchange value of the USD}

Units of foreign currency per USD

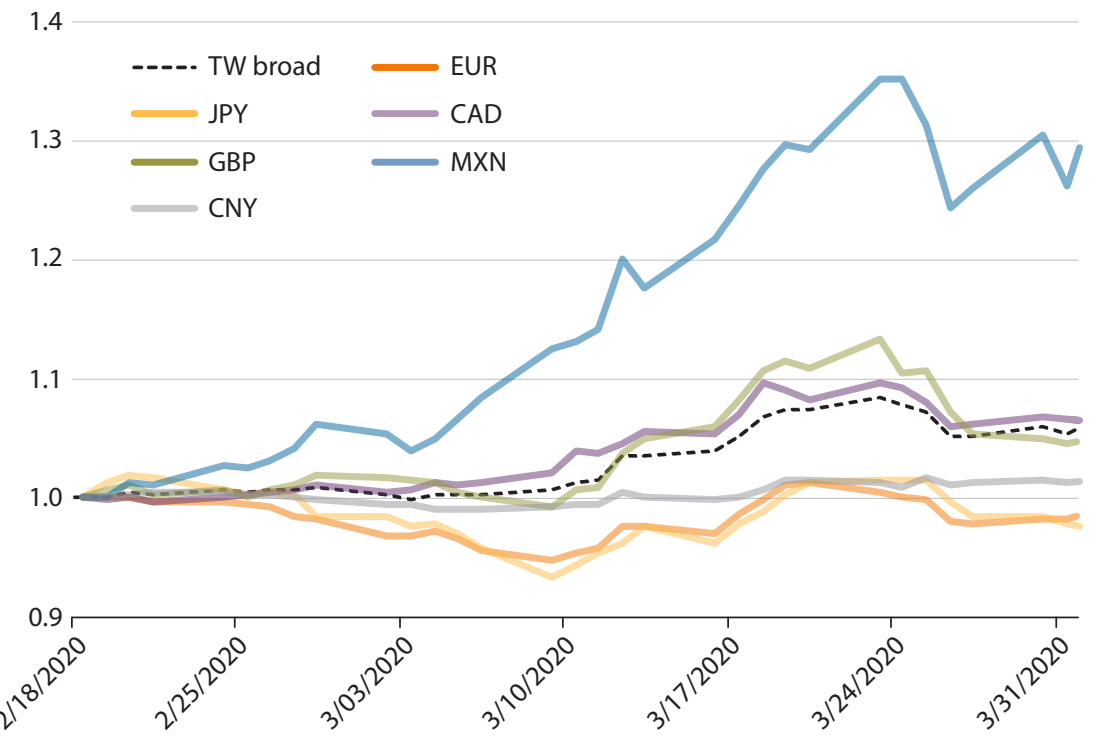

\section{B. Trade-weighted value of the USD}

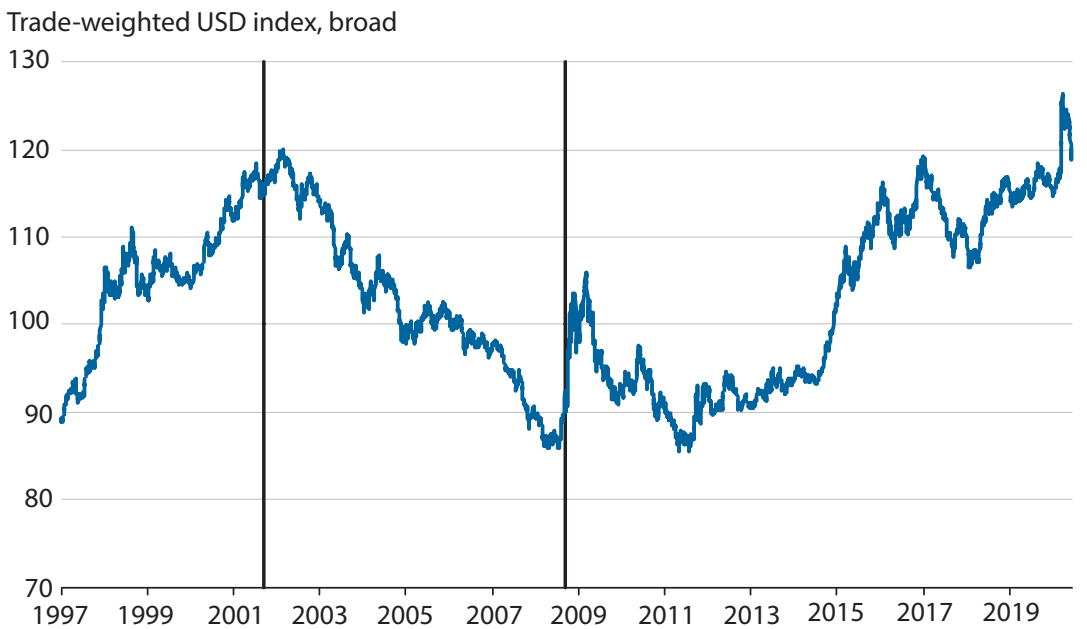

NOTE: Panel A shows the normalized foreign exchange value of the USD against a broad trade-weighted basket (TW broad), the Japanese yen (JPY), the British pound (GBP), the Chinese renminbi (CNY), the euro (EUR), the Canadian dollar (CAD), and the Mexican peso (MXN). All series are normalized to equal 1 on February 18, 2020. Panel B shows the tradeweighted value of the USD over a much longer sample. Vertical lines indicate September 11, 2001, and September 15, 2008 , the day of the Lehman Brothers collapse. The series in Panel B is constructed by splicing two broad currency indexes on January 2, 2006.

SOURCE: Haver Analytics. 


\section{Figure 6}

\section{Unemployment in the Four Monetary Areas}

\section{A. Unemployment rates, $2006-20$}

Percent unemployment

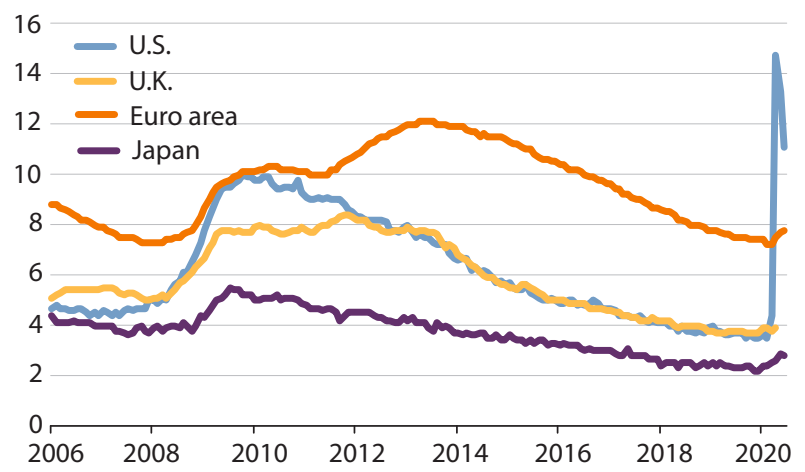

\section{Weekly U.S. unemployment claims, January 2006-June 2020}

U.S. weekly initial unemployment

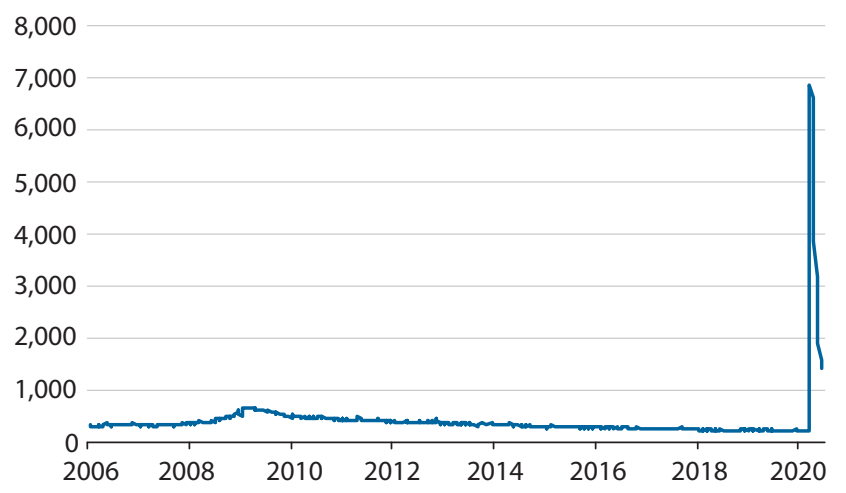

NOTE: U.K. unemployment data are through April 2020.

SOURCE: FRED ${ }^{\circledR}$, Federal Reserve Bank of St. Louis.

\section{B. Unemployment rates, June 2019-June 2020} Percent unemployment

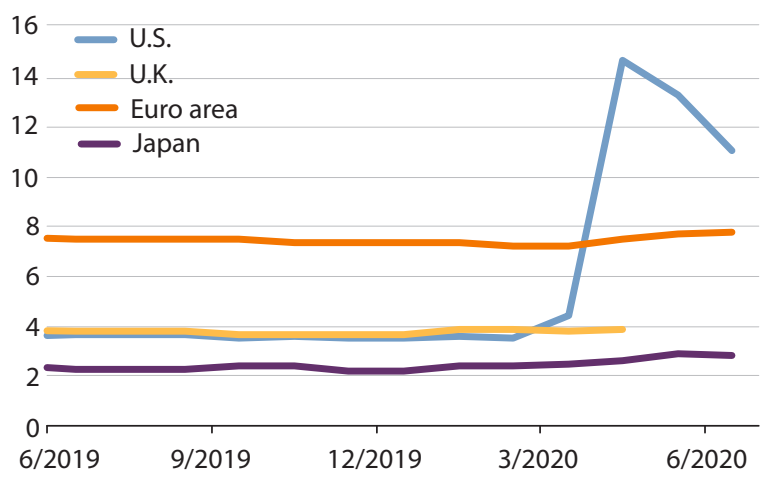




\section{Table 2}

IMF Annual Percentage Change in Real GDP Projections for 2019-21

\begin{tabular}{lccc} 
Area & $\mathbf{2 0 1 9}$ & $\mathbf{2 0 2 0}$ & $\mathbf{2 0 2 1}$ \\
\hline World & 2.9 & -4.9 & 5.4 \\
\hline Advanced economies & 1.7 & -8.0 & 4.8 \\
\hline United States & 2.3 & -8.0 & 4.5 \\
\hline Euro area & 1.3 & -10.2 & 6.0 \\
\hline Japan & 0.7 & -5.8 & 2.4 \\
\hline United Kingdom & 1.4 & -10.2 & 6.3 \\
\hline Emerging markets & 3.7 & -3.0 & 5.9 \\
\hline NOTE: Projections for 2020 and 2021 are as of June 2020. & & \\
SOURCE: IMF (2020d). & & & \\
\hline
\end{tabular}

among the hardest hit (Franck, 2020). Complicating matters, U.S. households had limited savings going into the episode. As of 2018, only 61 percent of U.S. adults could pay off an unexpected expense of $\$ 400$ by the end of the month (Board of Governors of the Federal Reserve System [Board of Governors], 2019c). Fed Chair Jerome Powell said that recovery could take more than a year (Timiraos, 2020).

Economies around the world were hit hard nearly simultaneously. IMF World Economic Outlook real GDP projections from the June 2020 issue, shown here in Table 2, provide a consistent format with which to compare likely conditions. The second column shows that the advanced economies grew sluggishly in 2019 , at a 1.7 percent rate. The third column illustrates the very substantial IMF-projected declines in real GDP in 2020: -4.9 percent growth in the world, -8.0 percent in advanced economies, -8.0 percent in the United States, -10.2 percent in the euro area, -5.8 percent in Japan, and -10.2 percent in the United Kingdom. .23 These GDP projections would be record-breaking negative numbers if they come to pass. The IMF further expects these economies to strongly rebound at (generally) 4 to 6 percent rates in 2021. 


\section{Figure 7}

\section{Timeline of Select Central Bank Actions}

December 31: Wuhan government confirms treatment of dozens of cases of (later named) COVID-19.
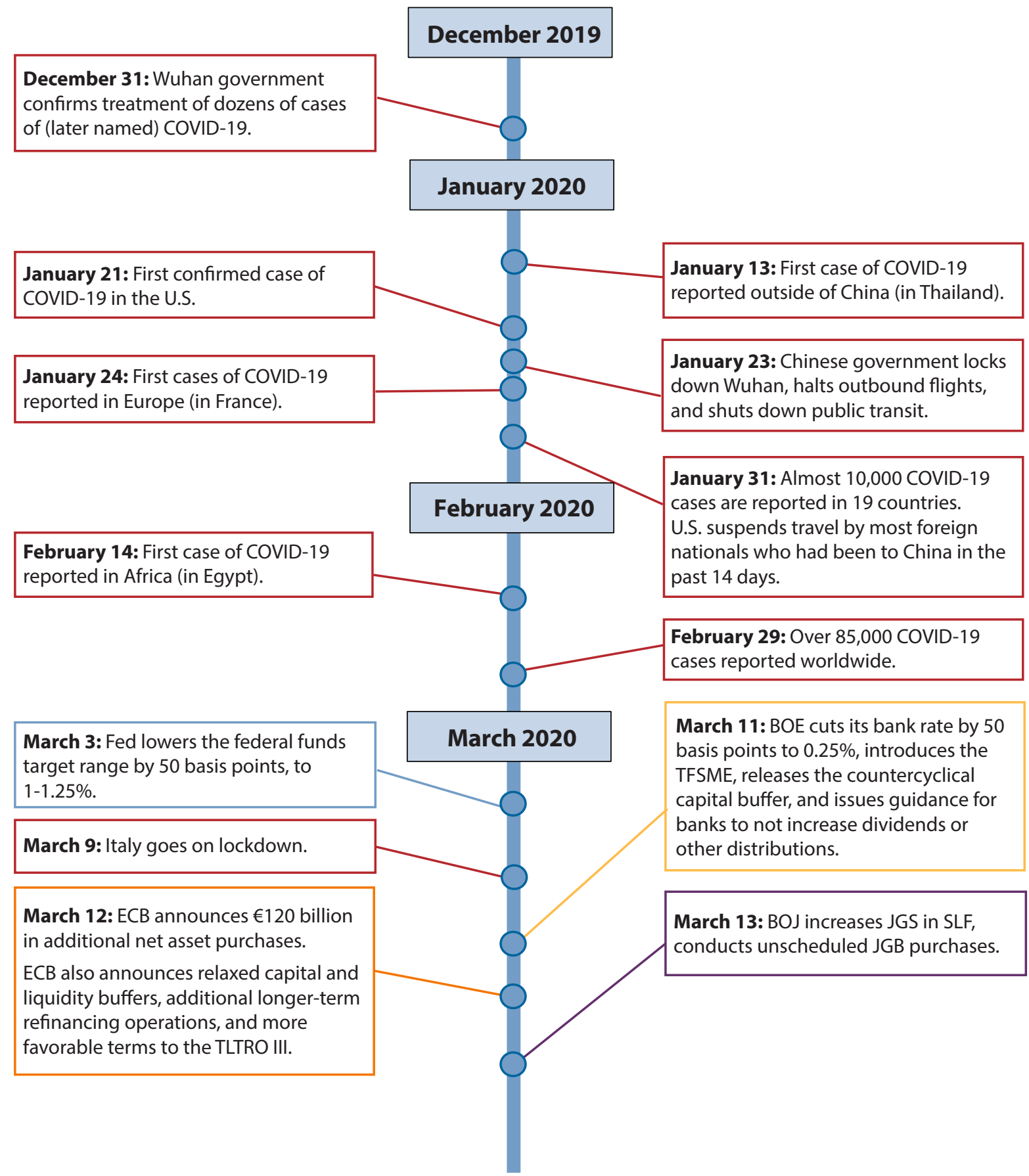

SOURCE: BBC, BOE, BOJ, ECB, Fed, Taylor (2020), and WHO. 
Figure 7, cont'd

\section{Timeline of Select Central Bank Actions}

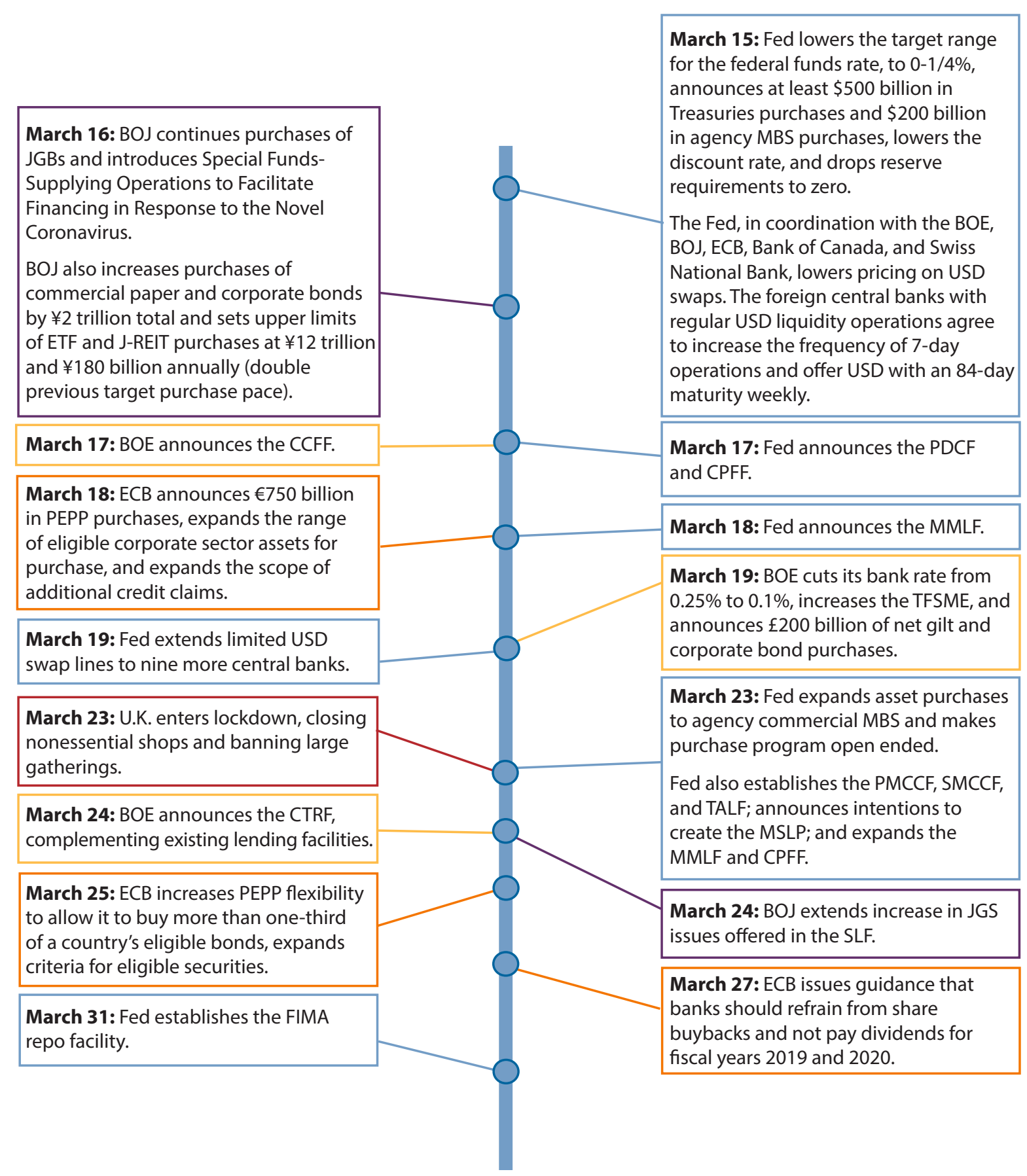

SOURCE: BBC, BOE, BOJ, ECB, Fed, Taylor (2020), and WHO. 
Figure 7, cont'd

\section{Timeline of Select Central Bank Actions}

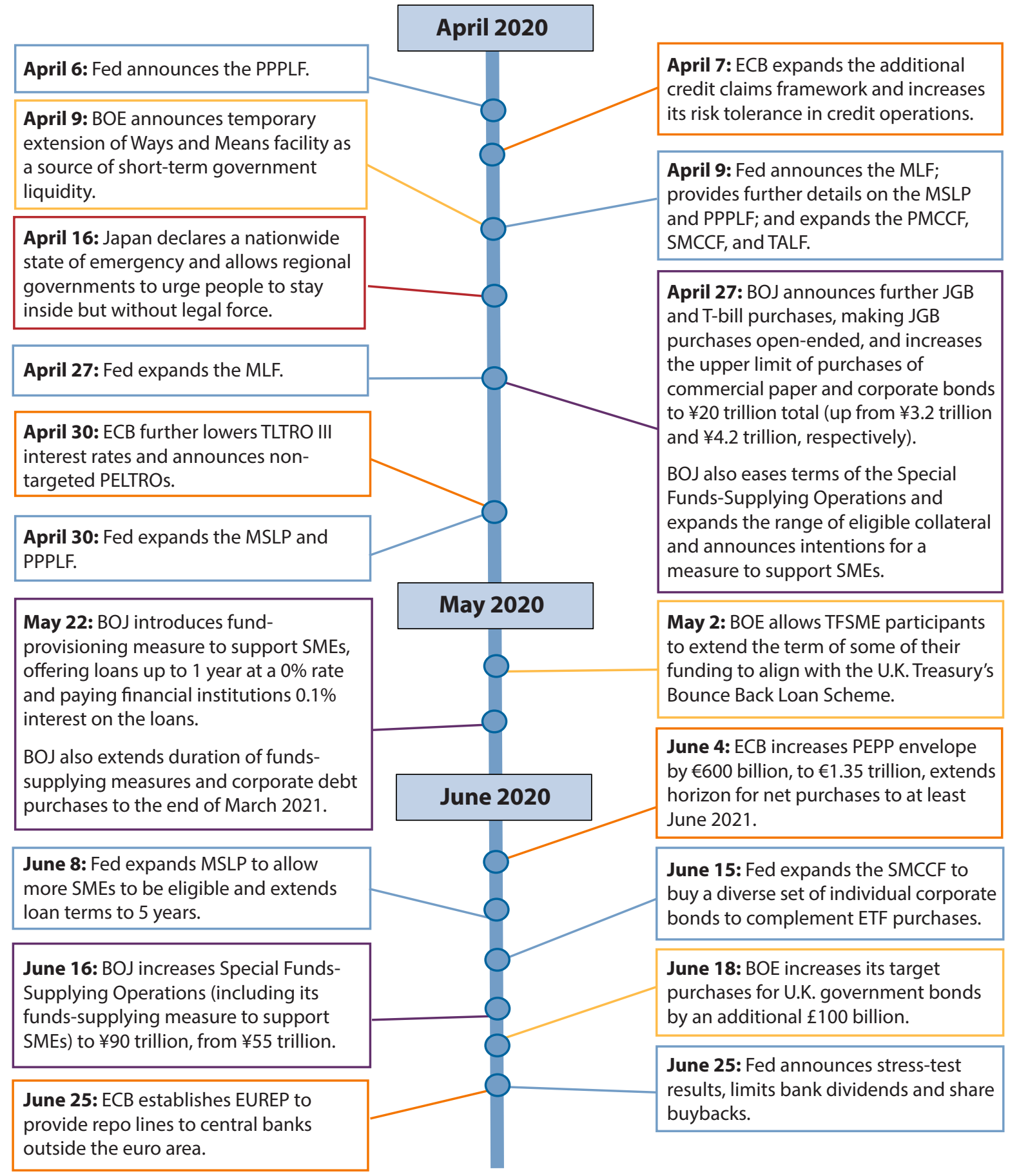

SOURCE: BBC, BOE, BOJ, ECB, Fed, Taylor (2020), and WHO. 


\section{CENTRAL BANK POLICY RESPONSES TO COVID-19}

Figure 7 provides a timeline of events and central bank policy responses, while Table 1 details the programs.

\section{1 Policy Rate Cuts}

The most common central bank action to stabilize financial markets and protect the functioning of the broader economy is to reduce short-term interest rates. Central banks also responded to the COVID-19 episode with short-rate cuts. Lower interest rates tend to raise asset prices, make credit more affordable, and increase the creditworthiness of borrowers.

Unfortunately, due to relatively low growth and low inflation since the GFC, short rates were already relatively low when the financial turmoil started in February 2020. As central bankers would say, there was not much conventional "policy space" (Bernanke, 2020). ECB and $\mathrm{BOJ}$ policy rates were already near zero and remained unchanged. Short-term interest rates were 1.5 to 1.75 percent and 0.75 percent in the United States and United Kingdom, respectively. In March, both the Fed and BOE lowered rates toward zero as the coronavirus spread and economic uncertainty rose. Panel A of Figure 8 provides a long-run perspective on policy rates prior to the current crisis, while Panel B details the specific rate cuts of the Fed and BOE. $\underline{24}$

\subsection{Broad Asset Purchase Programs}

With limited ability to further reduce short-term policy rates, central banks turned to long-term bond purchases to broadly reduce long-term yields, narrow asset purchases to aid the functioning of specific markets, and lending programs to expand credit for specific sectors. $\underline{25}$ These actions have expanded central bank balance sheets at record rates in both percentage terms and as a percentage of GDP (Figure 9). Table 1 details these programs.

Broad asset purchases are thought to lower yields through a combination of local supply, duration, and signaling effects. Bhattarai, Eggertsson, and Gafarov $(2015,2019)$ rationalize how central bank asset purchases can "signal" lower future short-term interest rates in a timeconsistent manner and thereby reduce current long rates. Removal of duration risk and local supply can produce portfolio rebalancing that reduces required yields. The literature on portfolio balance effects goes back to Tobin $(1958,1969)$, while more-recent contributions to this line of thought include Andrés, López-Salido, and Nelson (2004) and Vayanos and Vila (2009).

On March 12, the ECB’s Governing Council announced a €120 (\$135) billion set of purchases, which it followed on March 18 by announcing $€ 750$ ( $\$ 844)$ billion in purchases through the PEPP. Panel B of Figure 1 shows that this announcement appears to have immediately lowered yield spreads versus German bonds. Italian yield spreads fell over 75 basis points within days, and Spanish yield spreads fell almost 50 basis points. The ECB further expanded PEPP purchases on June 4 to $€ 1.35$ (\$1.52) trillion.

On March 15, 2020, the Fed announced that it would purchase at least $\$ 500$ billion in Treasuries and $\$ 200$ billion in agency MBS but soon followed with a March 23 announcement that made the purchase amounts open ended and added agency commercial MBS purchases. 


\section{Figure 8}

\section{Central Bank Policy Rates}

\section{A. Central bank policy rates, 2006-20}

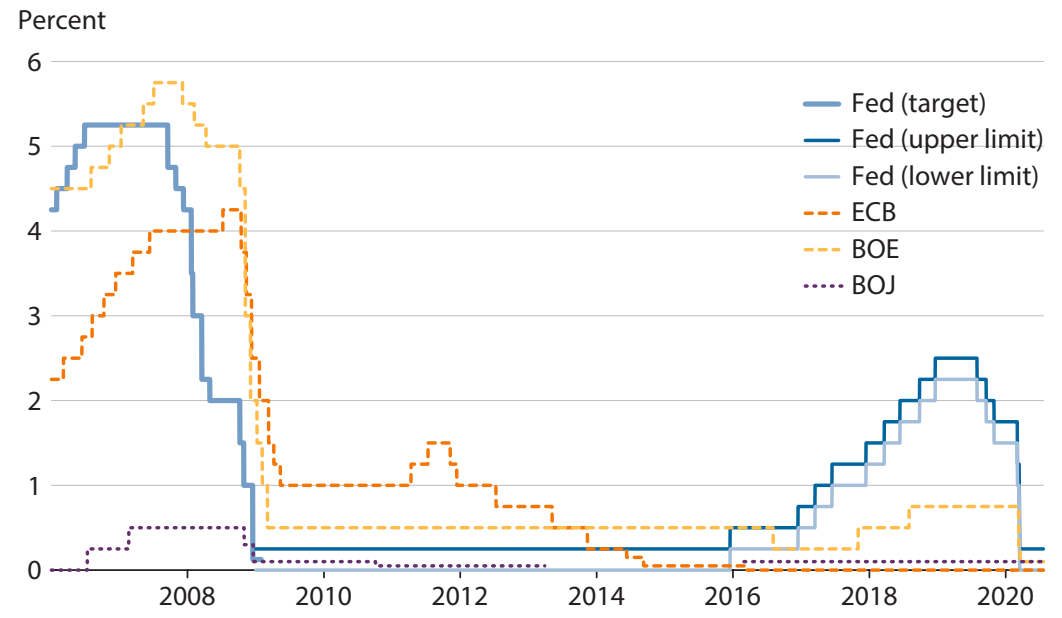

\section{B. Central bank policy rates, February 2020-May 2020}

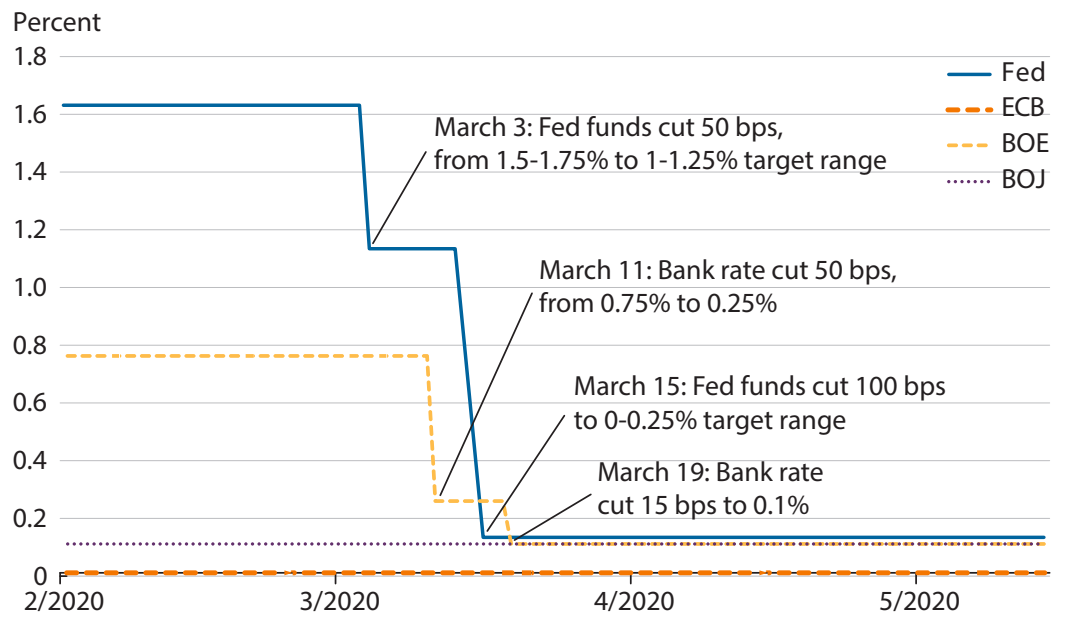

NOTE: Panel A: The data are from January 2006 to May 2020. The key policy rates for the BOE, Fed, ECB, and BOJ are, respectively, the official bank rate, the federal funds target rate, the main refinancing operations rate, and the uncollateralized overnight call rate. Starting in December 2008, the Fed began targeting a federal funds range rather than a target rate. Between April 2013 and February 2016, the BOJ did not set a target for the uncollateralized overnight call rate. Starting in February 2016, the BOJ resumed targeting a short-term interest rate, for which we report the BOJ's basic balance rate, which is part of a tiered system of interest rates. Panel B: bps, basis points. The figure displays interest rate cuts in early 2020. The graph uses the midpoint of the federal funds target range.

SOURCE: BOE, BOJ, ECB, Fed, and Haver Analytics. 
Haas, Neely, Emmons

\section{Figure 9}

\section{Central Bank Assets}

\section{A. Central bank assets, 2006-20}

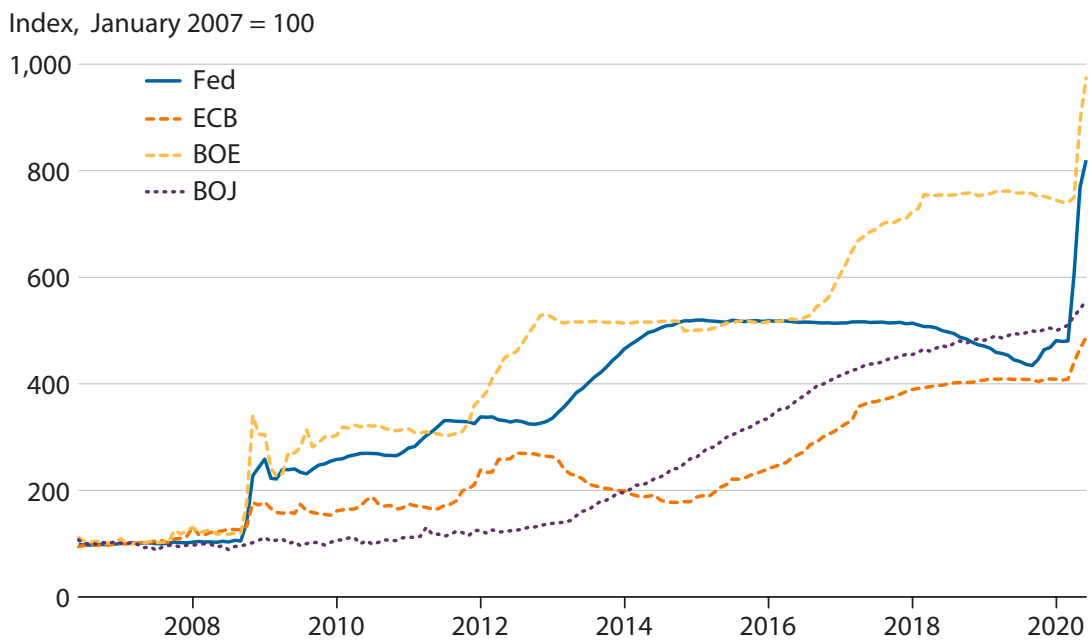

\section{B. Central bank assets as percentage of GDP, 2006-20}

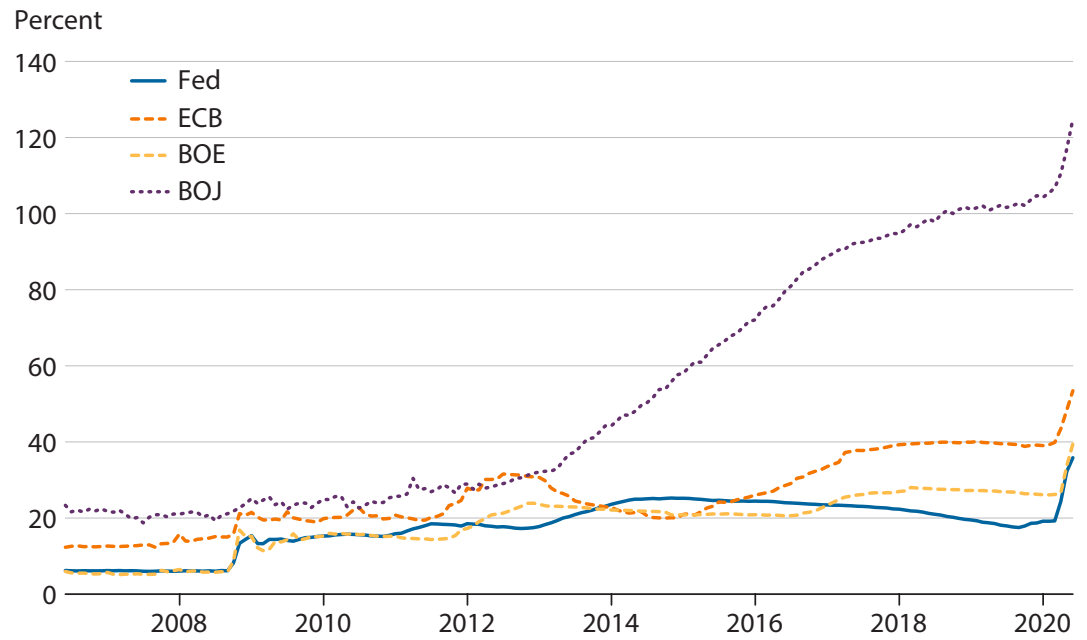

NOTE: Panel A shows asset holdings for the Fed, ECB, BOE, and BOJ, normalized to equal 100 in January 2007. Panel B shows asset holdings for the Fed, ECB, BOE, and BOJ, as a percentage of their respective nominal GDP through May 2020. Monthly GDP are interpolated from quarterly values, and 2020:Q2 GDP data are estimated based on OECD forecasts (at https://data.oecd.org/gdp/nominal-gdp-forecast.htm\#indicator-chart).

SOURCE: BOE, BOJ, ECB, Fed, Haver Analytics, and OECD. 


\section{Figure 10}

\section{Quarterly Change in Select Asset Purchases}

\section{A. Fed: Treasuries and MBS}

Quarterly change in holdings, \$ billions

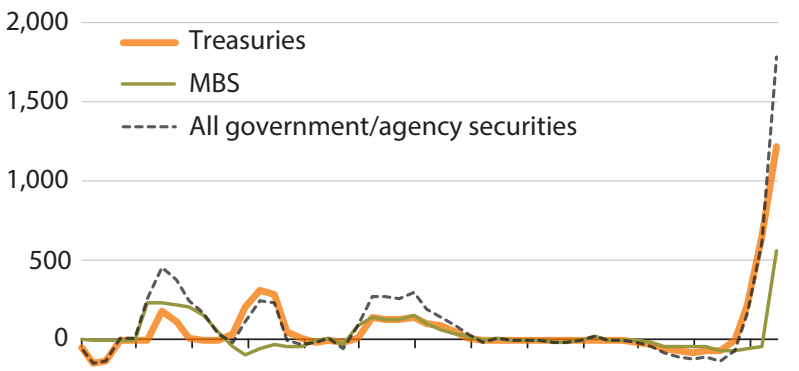

$-500$

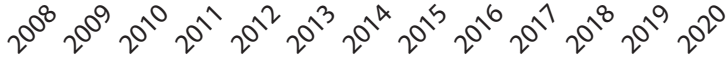

\section{BOE: APF}

Quarterly change in holdings, $£$ billions

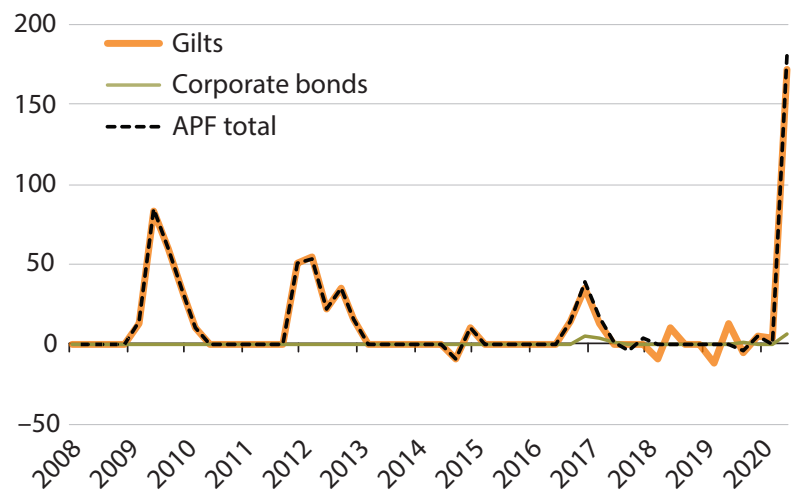

\section{B. ECB: APP and PEPP}

Quarterly change in holdings, $€$ billions

$500 \longrightarrow$ PEPP

$400-$ APP
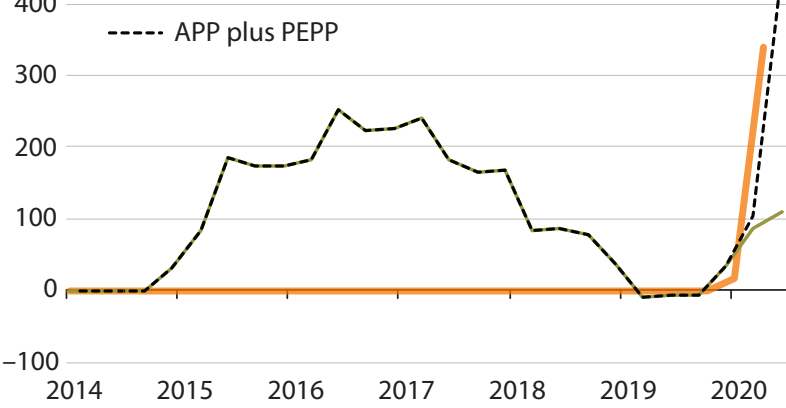

\section{BOJ: JGS}

Quarterly change in holdings, $¥$ trillions

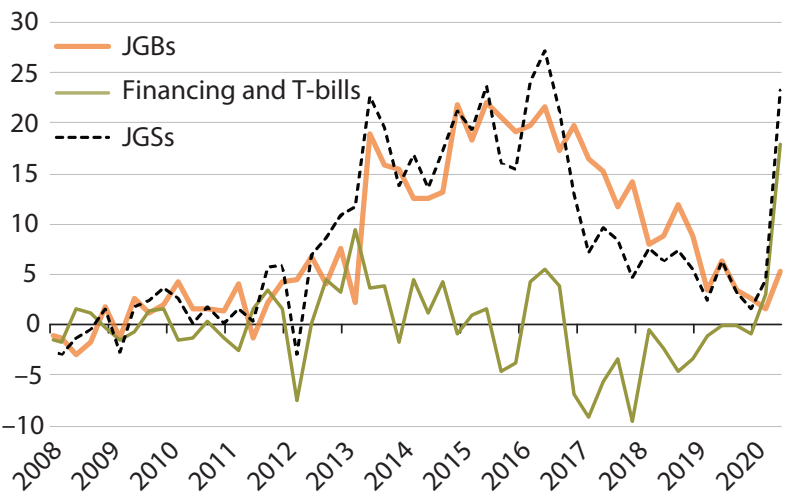

NOTE: The figures represent the quarterly changes in select assets from 2008 until 2020:Q2. The ECB data start at 2014, at the start of the APP. The data in the graph omits earlier ECB purchase programs.

SOURCE: BOE, BOJ, ECB, Fed, and Haver Analytics.

The BOJ has boosted its Japanese government bond (JGB) purchases, intending to purchase as necessary to keep 10 -year yields around 0 percent. The BOJ has also augmented purchases of commercial paper, corporate bonds, exchange-traded funds (ETFs) and Japanese real estate investment trusts (J-REITs). The BOE likewise voted to purchase $£ 200$ (\$250) billion in public and private bonds on March 19, then raised its purchase target by an additional $£ 100$ (\$125) billion on June 18 .

Figure 10 illustrates that the initial pace of central bank purchases was often unusually fast compared with past episodes. Fed purchases of Treasuries peaked at $\$ 75$ billion per day in late March, far outstripping the peak pace of $\$ 120$ billion per month during the previous crisis 


\section{Figure 11}

\section{Change in Total Assets, GFC and 2020 COVID-19 Crisis}

\section{A. Fed}

Change in assets as percentage of GDP

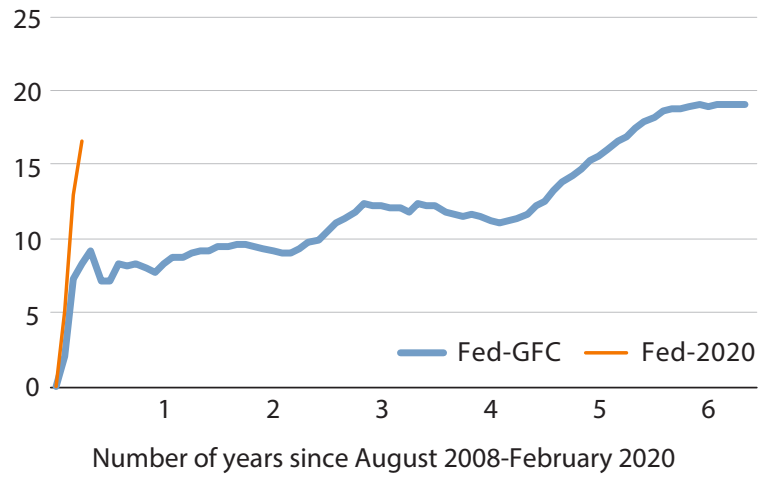

\section{BOE}

Change in assets as percentage of GDP

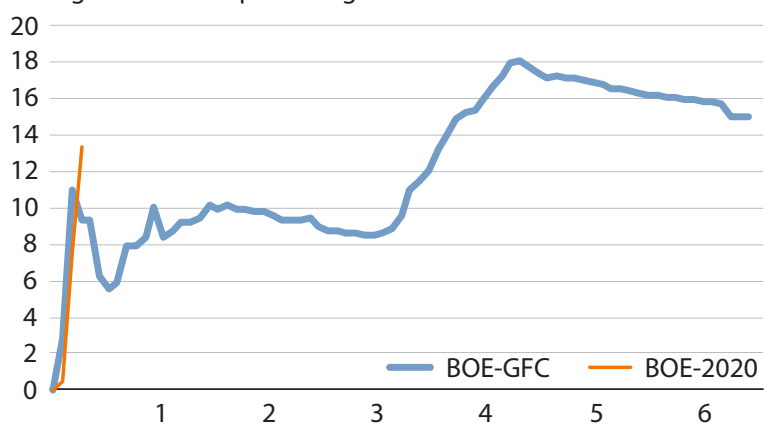

Number of years since August 2008-February 2020

\section{B. ECB}

Change in assets as percentage of GDP

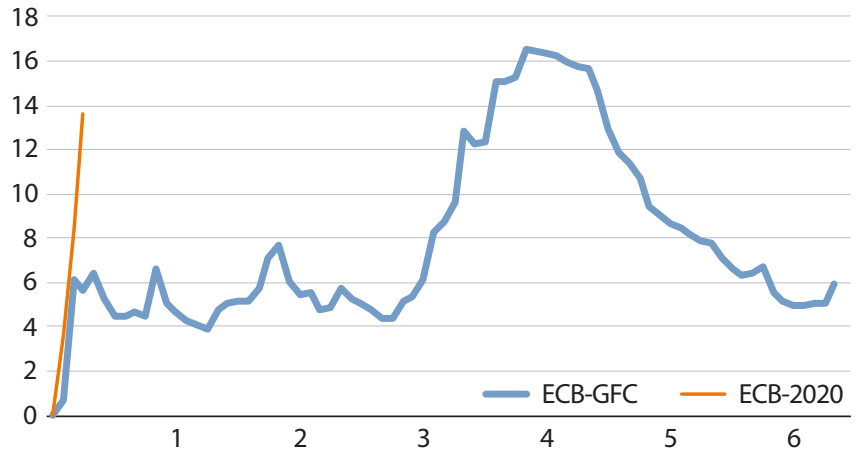

Number of years since August 2008-February 2020

\section{BOJ}

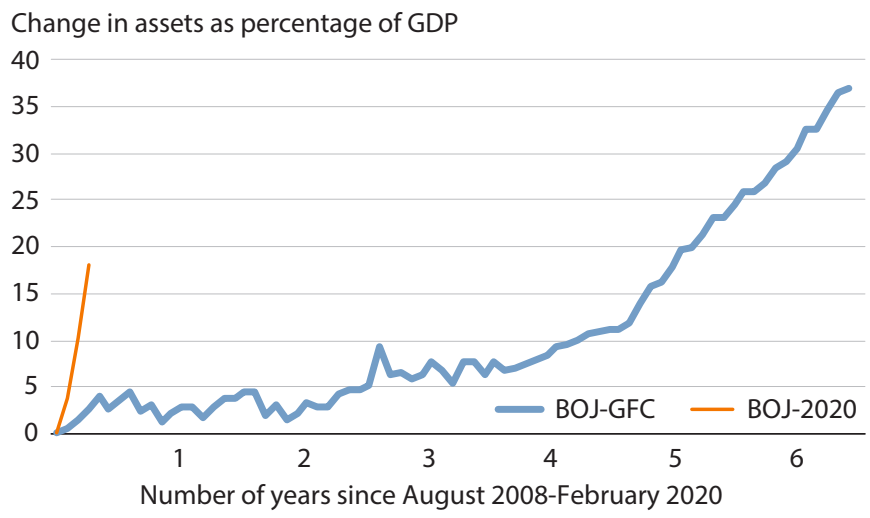

NOTE: The figures display the monthly change in total assets for each central bank since the beginning of the GFC and the 2020 crisis as a percentage of nominal GDP. August 2008, the month prior to the collapse of Lehman Brothers, is the reference month for the GFC. February 2020 is the reference month for the COVID-19 crisis. Monthly GDP values are interpolated from quarterly values, and 2020:Q2 GDP data are estimated from OECD forecasts: https://data.oecd.org/gdp/nominal-gdp-forecast.htm\#indicator-chart.

SOURCE: BOE, BOJ, ECB, Fed, Haver Analytics, and OECD.

(Haas and Neely, 2020, Figure 10). The BOE purchased $£ 13.5$ (\$16.9) billion of gilts per week from early April until late June, the fastest pace in the history of the BOE Asset Purchase Facility (APF). The BOJ ramped up corporate bond, commercial paper, and ETF purchases from April through June and increased its Japanese government securities (JGS) holdings, mainly driven by an increase in Treasury bill (T-bill) purchases. The ECB also bought bonds at a faster pace: In 2020:Q2, the PEPP and Asset Purchase Programme (APP) combined conducted more net asset purchases per month than at any point since the start of the APP (Figure 10). These purchases have sharply increased the size of each of the central banks' balance sheets (Figures 9 and 11). 
Figure 12

\section{Central Bank Ownership of Government Debt Outstanding}

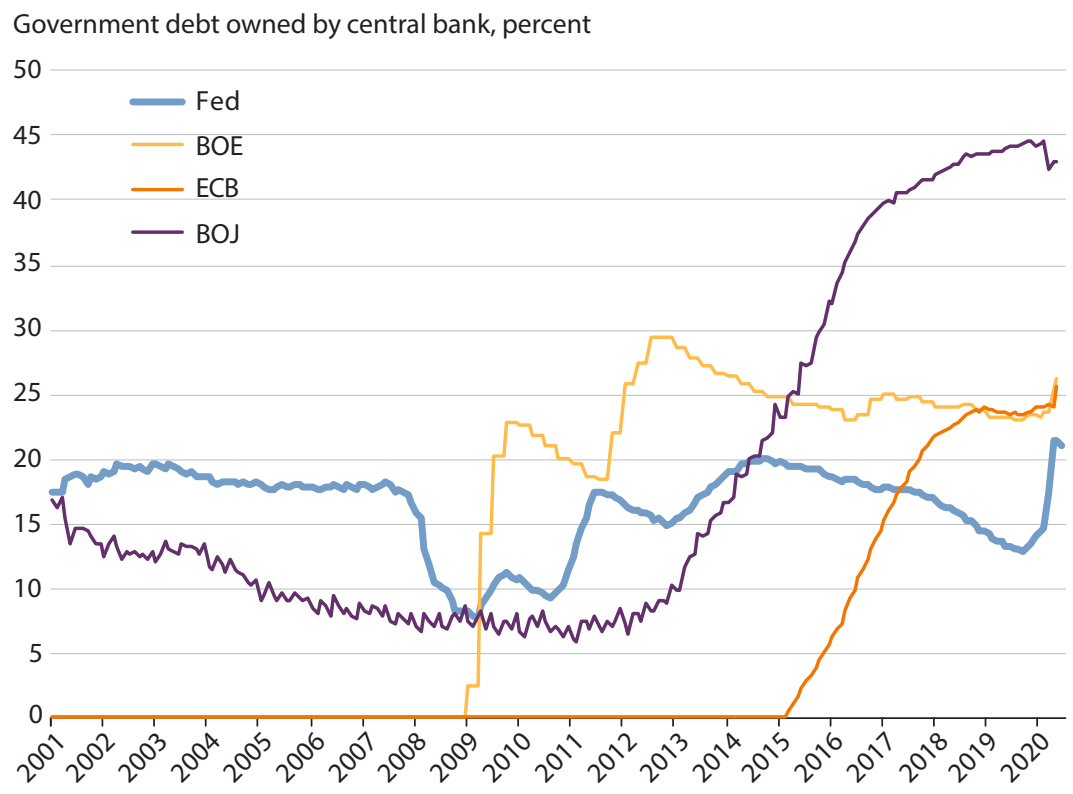

NOTE: The figure shows the percentage of government debt securities outstanding owned by the respective central bank. Fed data are U.S. Treasury securities held outright as a percentage of total marketable publicly held Treasury securities outstanding. ECB data are Public Sector Purchase Programme (PSPP) and PEPP euro area public sector securities held as a percentage of total euro area government debt securities. BOJ data are BOJ JGS holdings (including T-bills) as a percentage of total JGS. BOE data are total APF gilt holdings at market value as a percentage of total stock of British government securities.

SOURCE: ECB, BOJ, Deutsche Bank, Fed, Haver Analytics, and the Office of National Statistics.

Philip Lane, chief economist of the ECB, reports that the ECB's APP has focused on high-risk, high-yield countries, such as Italy, to stifle rising risk premia in its yields lest those increases cancel out stimulative effects (Skolimowski, 2020). Lane emphasizes the importance of flexibility in asset purchases over time and across jurisdictions. The ECB's need to choose how to allocate purchases across jurisdictions is a unique challenge for that central bank.

A prominent concern about the extensive asset purchases is that central banks may be buying so much of particular markets-or at least so much of the flow of issued assets-that they are distorting the price signals that these markets send. For example, the BOJ has purchased about 45 percent of government debt and has increased its balance sheet to over 120 percent of Japanese GDP due to the strong pace of its asset purchases since 2013 (Panel B of Figure 9 and Figure 12). The BOJ is also authorized to purchase up to 45 percent of outstanding Japanese commercial paper and 15 percent of longer-term corporate bonds (Editorial Board, 2020). Each of the four central banks have purchased over 20 percent of their respective outstanding government debt (Figure 12). At the end of June 2020, the Fed owned about 20 percent of marketable Treasury debt outstanding and 33 percent of MBS issued by Fannie Mae and Freddie Mac (Board of Governors, 2020b; Fannie Mae, 2020; Freddie Mac, 2020; and 


\section{Figure 13}

\section{Pending Home Sales}

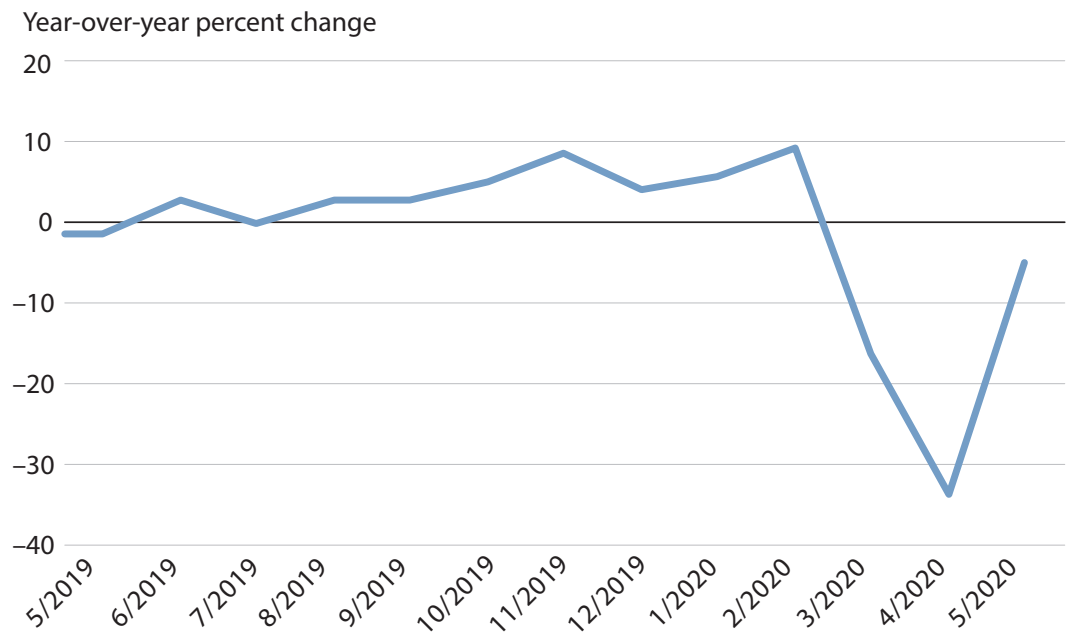

NOTE: The figure shows the year-over-year percent change in the National Association of Realtors Pending Homes Sales Index from May 2019 to May 2020. Data are seasonally adjusted and indexed to equal 100 in 2001.

SOURCE: Haver Analytics, National Association of Realtors.

U.S. Department of the Treasury, 2020). Given central banks' objectives to stabilize economies and financial markets, these large holdings may be unavoidable.

\subsection{Narrow Asset Purchases}

The Fed, $\mathrm{BOE}, \mathrm{BOJ}$, and $\mathrm{ECB}$, have all purchased assets to ease functioning in specific markets; that is, they have conducted narrow asset purchases. Table 1 describes the narrow purchase programs and lending facilities the central banks established in the wake of COVID-19. Central banks have tended to focus their narrow purchases on corporate bonds, commercial paper, and MBS.

Theoretical work of De Pooter, Martin, and Pruitt (2018); Pasquariello, Roush, and Vega (2020); Greenwood and Vayanos (2010); and Corsetti and Dedola (2016) has attempted to rationalize price effects from recurring central bank bond market purchases on various grounds.

Corporate Bonds and Commercial Paper. All four major central banks have supported the corporate bond market and provided credit to larger firms during the crisis. The BOE, BOJ, and ECB all announced increased corporate bond purchases, and the BOE and ECB expanded the eligible range of their corporate purchases. The Fed, previously unwilling to purchase corporate bonds, established the PMCCF and SMCCF on March 23. The PMCCF allows the Fed to purchase qualifying corporate bonds at issuance, while the SMCCF was created to purchase investment-grade bonds of U.S. companies and U.S.-listed ETFs that provide broad exposure to those bonds. $\underline{26}$ The U.S. Treasury purchased equity in the special purpose vehicle (SPV) established for the PMCCF and SMCCF with resources from the Exchange Stabilization Fund (ESF). .27 Panel A of Figure 1 shows that these announcements preceded substantial 
declines in corporate yields, as much as 3 percentage points for the high-yield OAS (optionadjusted spread) after the March 23 PMCCF/SMCCF announcements, indicated by the vertical line.

The BOJ and ECB announced increased commercial paper outright purchases, while the Fed and BOE established facilities to purchase commercial paper. On March 17, the Fed reestablished its CPFF, while the BOE announced the Covid Corporate Financing Facility (CCFF) to support U.K. firms by buying commercial paper on terms similar to those prior to the COVID-19 crisis.

MBS TBA. The housing market is a cyclically volatile sector and was a particular target of the Fed's first unconventional asset purchase program in 2008-10, that is, "QE1." Despite the unusual source of the COVID-19 crisis, housing was one of the first sectors to be affected. Pending home sales slowed significantly during March and April as bad news about the spread of COVID-19 accumulated and the stock market turned down (Figures 3 and 13). To provide liquidity and facilitate trading of agency MBS, the March 15 FOMC announcement included plans to purchase at least $\$ 200$ billion in agency MBS, concentrated on recently produced coupons in 30-year and 15-year fixed-rate agency MBS in the to-be-announced (TBA) market. $\underline{28}$ The FOMC expanded these purchases on March 20 and then made them open ended on March 23.

J-REITs and Equity ETFs. In addition to public securities and corporate debt, the BOJ has also been purchasing J-REITs and equity ETFs. On March 16, the BOJ doubled the annual purchase limits of J-REITs and ETFs and has been accumulating these assets at record rates.

\title{
4.4 Lending Facilities
}

Asset purchases greatly increased bank reserves, but these safe liquid assets are in high demand and unevenly distributed among banks; so, particular markets may still lack shortterm credit. According to Fed Chair Powell, investor risk aversion rose so sharply that extraordinary interventions by the Fed were required:

\begin{abstract}
As a more adverse outlook for the economy associated with COVID-19 took hold, investors exhibited greater risk aversion and pulled away from longer-term and riskier assets as well as from some money market mutual funds. To help stabilize short-term funding markets, we lengthened the term and lowered the rate on discount window loans to depository institutions. The Board also established, with the approval of the Treasury Department, the Primary Dealer Credit Facility (PDCF)...the Commercial Paper Funding Facility, or CPFF, and the Money Market Mutual Fund Liquidity Facility, or MMLF. Both of these facilities have equity provided by the Treasury Department to protect the Federal Reserve from losses. Indicators of market functioning in commercial paper and other short-term funding markets improved substantially and rapid outflows from prime and tax-exempt money market funds stopped after the announcement and implementation of these facilities. (Powel 2020a)
\end{abstract}

Table 1 details the recently introduced lending facilities from the four central banks and the targeted sectors and provides links to information on the facilities' purposes and operations. Many of these facilities were directly analogous to initiatives taken in the wake of the 2007-09 crisis. 
To ensure the continued availability of consumer loans, on March 23, the Fed established the TALF under Section 13(3) of the Federal Reserve Act. $\stackrel{29}{ }$ Through an SPV, the Fed will initially loan up to $\$ 100$ billion to issuers of AAA-rated ABS that are backed by receivables, such as small-business loans, auto loans, credit card loans, and education loans. Although these loans are nonrecourse, the value of the ABS (collateral) will protect the Fed against losses to some degree. The U.S. Treasury's ESF will provide the first $\$ 10$ billion in capital to cover any losses.

In addition to rebooting several credit/purchase facilities from the 2007-09 crisis, the Fed has created new facilities to lend more than $\$ 2.3$ trillion to municipalities, corporations, and small and mid-sized enterprises (SMEs). $\frac{30}{.}$ Of these new facilities, the MSLP is one of the most innovative. This program permits the Fed to use an SPV to purchase bank loans (95 percent of each loan) made to SMEs, which frees up the bank's capital to make new loans. The MSLP, along with the Paycheck Protection Program Liquidity Facility (PPPLF), is designed to stimulate bank lending, similar in purpose to bank lending incentive programs that the other three major central banks have operated, such as the BOE's Term Funding Scheme (TFS), the ECB's targeted/pandemic longer-term refinancing operations (TLTROs/PELTROs), and the BOJ's Stimulating Bank Lending Facility (SBLF) and new Special Funds-Supplying Operations to Facilitate Financing in Response to the Novel Coronavirus.

The BOE has restarted the TFS with an estimated $£ 100$ (\$125) billion in funding for bank lending but has added incentives for lending to SMEs. This TFSME program augments the BOE's new commercial paper and repo facilities. Similarly, the ECB has prioritized nonfinancial lending by creating incentives for banks to lend to businesses and households in its long-term lending program (TLTRO III). The BOJ has established new Special Funds-Supplying Operations programs to aid corporate, SME, and other private lending and expanded the Securities Lending Facility (SLF) to ensure repo market stability (see Table 1D). These programs are in addition to their previously established facilities to encourage bank lending to the nonfinancial sector, the SBLF and the Growth-Supporting Funding Facility (GSFF).

An extraordinary aspect of the current situation is that the ECB and BOJ are actually charging negative interest rates on bank borrowing. That is, these central banks are paying banks to lend money (Kihara, Canepa, and Schneider, 2020). The ECB's TLTRO III loans banks money at -1 percent on the condition that they don't reduce their loans. The BOJ is not so generous but is still paying 0.1 percent to banks that participate in its new Special FundsSupplying Operations (Kihara, Canepa, and Schneider, 2020).

\subsection{International Facilities}

Central banks can lend money and purchase assets indefinitely because they can create unlimited nominal amounts of their own currencies. The widespread use of the USD in international financial transactions gives the Fed a special role in international financial stability. Foreign central banks often would like to make loans in USD to firms doing business in USD, but they cannot create USD as they can their own domestic currencies. Foreign central banks could obtain USD by selling their USD-denominated foreign exchange reserves, buying USD with their domestic currency on foreign exchange markets, or borrowing USD, but 
these actions might affect asset prices in undesirable ways, driving up U.S. yields or the value of the USD.

To meet this international demand for the USD, the Fed expanded its foreign exchange swap lines with other central banks and created a repo facility from which foreign and international monetary authorities (FIMA) can borrow USD from the Fed. $\frac{31}{1}$ Providing USD to foreign central banks allows them to function as a lender of last resort in USD and to mitigate the consequences of fire sales of risky assets. This practice indirectly aids the U.S. economy by improving conditions for U.S. trading partners and encouraging the international use of the USD. The Fed has used swap lines to help manage financial crises after September 11, 2001, and during the GFC of 2007-09, but the repo facility is novel. Table 1A details these facilities.

Since the establishment of the euro in 1999, financial markets have increasingly used that currency, and the ECB has also established new arrangements to provide increased access to it. On June 25, 2020, the ECB established the Eurosystem Repo Facility for Central Banks (EUREP), a new facility to provide repo lines to non-euro area central banks, complementing their existing swap and repo lines. This facility will be available until June 2021. The ECB also added new swap lines with the central banks of Croatia and Bulgaria and reactivated their swap line with Denmark's central bank.

\subsection{Regulatory Changes}

In addition to their traditional roles as a lender of last resort and monetary authority, central banks usually have substantial regulatory responsibilities with which they can influence financial markets. International regulators quickly made important adjustments when the crisis hit (Board of Governors, 2020a, and IMF, 2020a,c):

- The Fed and other regulatory agencies encouraged U.S. banks to offer loan modifications to bank customers affected by COVID-19, stating that financial institutions generally do not need to categorize these modifications as troubled debt restructurings.

- National regulatory authorities in most European countries and Japan also encouraged banks to restructure loan terms and provide payment holidays when feasible.

- Regulators in all countries allowed banks to defer recognition of credit losses for purposes of regulatory capital computation that resulted from the ongoing introduction of a forward-looking approach to loan-loss provisioning. $\frac{32}{3}$

- U.S. supervisory agencies temporarily refocused on off-site monitoring of regulated institutions, suspending most regular examinations for institutions with less than $\$ 100$ billion in assets.

- U.S. banks were allowed to exclude Treasury securities and deposits held at the Fed when calculating their capital requirements.

- The Fed brought reserve requirements down to zero.

The Fed's 2020 supervisory stress test, designed to evaluate the resiliency of bank capital to severe economic and financial stress, proceeded as originally announced despite the reservation of some banks about the exercise. To gauge the impact of the unfolding crisis, the Fed required banks to conduct additional sensitivity analyses of three downside scenarios. The Fed 
also tightened capital-distribution limits and required large banks to submit new longer-term capital plans (Board of Governors, 2020c). In contrast, the Bank of England cancelled its supervisory stress test (BOE, 2020c).

Like the Fed, Japan's Financial Services Agency encouraged regulated financial institutions to work with borrowers in light of greatly increased financial stress (Financial Services Agency, 2020).

The BOE reduced the U.K. countercyclical buffer rate to 0 percent to release up to $£ 190$ (\$238) billion of additional bank liquidity (BOE, 2020b). This buffer had previously been due to increase from 1 percent to 2 percent. $\underline{33}$

The ECB focused on reducing banks' financing costs, including costs of directly borrowing from the central bank and reducing banks' required capital levels (Schnabel, 2020). Perhaps its most important supervisory action was to temporarily lower banks' capital requirements for market risk and to allow banks to fully use their capital and liquidity buffers. $\frac{34}{\underline{4}}$

\subsection{International Policy Comparison}

Similarities. In many ways, the four major central banks responded very similarly. They each pushed policy rates toward zero-or held them at negative levels; implemented asset purchase programs; relaxed capital requirements; and instituted initiatives to support SMEs, the repo market, and corporate bond markets. The central banks have also moved together toward buying some nontraditional assets, such as commercial paper and corporate bonds. In general, the central banks have sought to ensure two-way asset markets (i.e., sufficient market liquidity to allow large purchases and sales to take place without moving prices unduly) and access to credit.

The responses of the central banks are notably similar, in contrast to the stark differences in their responses to the GFC. For example, the ECB did not start a large, broad asset purchase program until early 2015, years after other central banks implemented their programs, initially responding with the more narrowly purposed initiatives such as supporting sovereign bond markets (Fawley and Neely, 2013; Karson and Neely, forthcoming; and Altavilla, Carboni, and Motto, 2015). And unlike the other three central banks, the Fed did not buy corporate bonds until the 2020 crisis, nor did they previously use bank lending incentive schemes.

Differences. There are also policy differences, however. Prominently, the BOJ and ECB have embraced slightly negative deposit rates, while the Fed and BOE have not. Former Chair Bernanke (2016) outlines several reasons why the Fed did not turn to negative rates after the GFC of 2007-09: First, lacking much experience with negative rates, Fed economists may have underestimated the potential to push rates below zero. Burke et al. (2010) suggested that short rates below -30 to -35 basis points might induce a widespread conversion of bank reserves to cash. This seems to understate the potential of negative rates, as the costs associated with holding cash have allowed several central banks to push interest rates 50 or 100 basis points below zero. Second, former Fed Chair Janet Yellen said that it was not clear that the Fed can legally impose negative rates on reserve deposits (C-SPAN, 2016). Third, officials worried that negative rates might force (or induce) money market funds to "break the buck" and that ensuing widespread withdrawals would endanger the health of that part of the financial system (Neely, 2020). $\underline{35}$ 
More broadly, negative rates tend to compress bank profit margins, functioning as a tax on banks (Waller, 2016; Brunnermeier and Koby, 2018; and Bhattarai and Neely, forthcoming). Indeed, BOE Governor Andrew Bailey cited concerns over banks' net interest margins and a lessening effectiveness of cuts as rates approach their zero lower bound but would not rule out implementation of negative rates entirely (Douglas and Hirtenstein, 2020). Similarly, Schnabel (2020) cites the pressures that more negative rates might put on the financial system in explaining the ECB Governing Council's decision to not push rates further below zero. And a former BOJ board member, Sayuri Shirai, has spoken out on the costs and limited benefits of negative rates (as quoted in Kihara, Canepa, and Schneider, 2020): "It doesn't make sense to deepen negative interest rates and hurt banks when you're actually trying to encourage them to lend more. It's a tool that is very hard to use at a time like now." Current BOJ Governor Haruhiko Kuroda agreed that he saw no need for deeper negative rates (as quoted in Kihara, Canepa, and Schneider, 2020): “At this moment, we don't think it's necessary.”

Perhaps even more radical than negative deposit rates are the negative interest rates that the $\mathrm{ECB}$ and $\mathrm{BOJ}$ are paying on borrowing; the Fed and $\mathrm{BOE}$ have so far not done so. Interest rates on the ECB's TLTRO III program were lowered to -0.5 percent and can be as low as -1 percent for banks that meet a 0 percent lending growth threshold, essentially paying banks to not reduce their lending to the nonfinancial sector (European Central Bank, 2020). Similarly, the BOJ offers 0.1 percent interest to banks on the amount that the banks lend using the BOJ's Special Funds-Supplying Operations, in effect compensating banks to lend to the nonfinancial sector (Kihara, Canepa, and Schneider, 2020, and Dreyer and Nygaard, 2020). In contrast, the Fed's PPPLF and the BOE's TFSME are priced at positive rates: at or slightly above the discount rate and the BOE's bank rate, respectively.

Lending Program Approaches. Each central bank has incentivized bank lending to the nonfinancial sector in different ways. Unlike the other central banks, the Fed has directly funded lending to SMEs through the MSLP by purchasing 95 percent of each long-term loan provided by the program. $\frac{36}{}$ By purchasing loans from banks, the MSLP removes a balance sheet constraint on further loans. Another way to encourage loans is to offer long-term, lowrate credit to banks based on their quantities of nonfinancial lending, as the BOE, BOJ, and ECB have done. $\underline{37}$ The ECB's TLTRO III and BOE's TFSME provide interest rate incentives to banks to maintain their net nonfinancial lending (BOE, 2020b, and ECB, 2020). The TFSME also includes quantity incentives for higher SME lending. One difference is that the MSLP's purchases of SME loans exposes the Treasury/Fed more directly to the risk of losses than do the bank incentive programs of the other central banks.

The central banks have worked with fiscal authorities in different ways. The U.S. Treasury has pledged up to $\$ 454$ billion to cover losses from Fed lending, allowing the Fed to accept greater risk in lending. Similarly, the U.K. Treasury has pledged to cover any losses from the BOE's CCFF and APF (Bailey 2020a,b). However, the ECB and BOJ have no explicit fiscal backstop for their lending programs, and the BOJ has already incurred losses on their ETF purchases, though all major central banks enjoy the implicit backing of the sovereign (Sano and Kaneko, 2020).

Differences in financial systems also played a role in why each central bank chose certain policy measures. For example, the Fed has instituted the MMLF to support the uniquely 
important U.S. money market mutual fund sector and, as discussed in Section 4.5, the Fed and ECB's foreign monetary authority repo facilities and foreign exchange swap lines result from the heightened role of the USD and the euro in the world economy. $\frac{38}{3}$

Asset Purchases. All four central banks purchased their respective government's bonds as well as corporate bonds and commercial paper. While each of the four central banks purchased long-term bonds to reduce long yields, the potential magnitudes of the purchases differed. While the BOE and ECB set upper limits on their purchases, the Fed and BOJ employed open-ended asset purchase programs contingent on the state of the economy (Bullard, 2010). $\underline{39}$ The BOJ implemented such an open-ended JGB-buying scheme despite the fact that it had not come close to hitting its previous annual JGB target of $¥ 80$ trillion ( $\$ 744$ billion) in prior years (Fujikawa, 2019).

As mentioned in Section 4.3, the BOJ and Fed have expanded narrow purchases of additional asset types. The BOJ has been buying equity ETFs and J-REITs, while the Fed has been purchasing agency MBS. $\underline{40}$

\subsection{Unwinding Crisis-Era Policies}

As the financial crisis recedes, central banks must exit from their crisis-induced policies. Extended periods of lax financial conditions contribute to the creation of "zombie" banks and other firms that survive only when interest rates are very low. Their survival inhibits the reallocation of resources and reduces growth (Caballero, Hoshi, and Kashyap, 2008, and Lee and Davis, 2020). A belated return to non-crisis monetary policy risks the emergence of fiscal dominance, whereby financial and monetary policies become subordinated to the financing of government expenditures. In other words, very low interest rates may be appropriate in a crisis, but they could also delay or prevent needed adjustments in both the private and public sectors.

To avoid this danger, many emergency credit-market measures are explicitly time-limited, although some can be extended. Some lending facilities are created with terms that will become unattractive as soon as normal market functioning returns, causing them to wind down naturally. The Fed's MSLP, for example, is designed to be used only when no better market alternatives are available. Open-ended actions and programs, such as interest rate cuts and large-scale asset purchases, on the other hand, require detailed planning to exit.

During its dramatic balance sheet expansion following the GFC of 2007-09, in June 2011, the Fed began to communicate principles underlying its normalization strategies for interest rates and its balance sheet (Board of Governors, 2011). Even earlier, Fed Chair Ben Bernanke discussed how the Fed would wind down its special lending facilities (Bernanke, 2010). Jean-Claude Trichet, president of the ECB, likewise spoke in detail about exit strategies in late 2009 (Trichet, 2009).

Central banks generally significantly altered their initial timetables and targets, for example, as in Board of Governors (2014 and 2019a). But financial markets generally easily digested such changes because they were well communicated. One exception was the so-called "taper tantrum" in 2013, when Chair Bernanke's public comments about the Fed tapering the pace of its asset purchases triggered a sell-off in bond markets (Neely, 2014). 
Given that economic weakness may last longer than financial fragility, central banks must decouple the unwinding of emergency financial policies from expansionary monetary policy. Too-rapid withdrawal of emergency support for financial institutions could destabilize credit flows and market liquidity. On the other hand, failing to prune back financial sector support in a timely manner would distort financial incentives and give advantages to selected banks, other financial institutions, and investors.

From a longer-term perspective, emergency central bank policies that seek to bolster the financial system must be weighed against the aggravation of moral-hazard incentives that will outlast the crisis. Support given in the past crisis may be expected in the next one, affecting asset prices and risk-taking behavior in the interim. The risk of a public backlash against the financial sector and policymakers seen to support it at the expense of the broader public interest can result in legislative changes that reduce the ability of central banks to act in future emergencies.

\section{DISCUSSION AND CONCLUSION}

This article has reviewed the sudden financial turmoil associated with the outbreak of COVID-19 and detailed the central bank policy responses. Uncertainly about economic activity created financial conditions that were similar to or even worse in some ways than the conditions during the GFC of 2007-09. The initial real consequences of this pandemic were unusually sudden and severe, with U.S. unemployment rising to levels unseen since the Great Depression.

Although the cause of the COVID-19 crisis was quite unlike that of the GFC of 2007-09, many symptoms were similar. For example, both crises spawned flights to safety that produced fire sales of risky assets. Many of the policies to alleviate those symptoms were also similar in kind, but central banks responded with unusual speed and vigor as a result of their post-2008 experience with unconventional policies.

The Fed and BOE cut short-term interest rates, while the ECB and $\mathrm{BOJ}$ maintained rates that were already at or below zero. All four central banks introduced or expanded broad asset purchases, special bank-lending facilities, and narrow asset purchase facilities. Extraordinarily, the ECB and $\mathrm{BOJ}$ are actually paying negative interest rates on bank borrowing. With the USD and euro playing important roles on international financial markets, the Fed and the ECB expanded swap lines and created repo facilities for international monetary authorities. These measures seemed to be largely successful in maintaining the functioning of financial markets.

The crisis has prompted unprecedented cooperation between fiscal and monetary authorities. Congress appropriated $\$ 454$ billion for Treasury injections of capital to Fed programs, while the U.K. Treasury offered indemnity on BOE asset purchase and CCFF losses (Timiraos and Hilsenrath, 2020, and Bailey 2020a,b). The Fed, BOJ, and BOE have also designed some of their lending programs to support fiscal authority initiatives. For example, the Fed's PPPLF and BOJ's Special Funds-Supplying Operations for SMEs provide funding for banks that use government SME lending programs, encouraging banks to use these fiscal policy programs 
and lend more to SMEs. Such cooperation may make central bankers nervous about retaining their independence.

Although the major central banks have taken unusually bold steps to achieve their mandates by supporting financial markets and economic activity, they are not out of ammunition. If they thought it appropriate, all the central banks could make more aggressive use of contingent forward guidance to shape expectations about the future path of short-term interest rates. The Fed could reopen the TAF and provide greater incentives for bank lending. The Fed and the $\mathrm{BOE}$ could follow the $\mathrm{ECB}$ and $\mathrm{BOJ}$ and push rates negative. Otherwise, the other central banks could follow the BOJ in controlling the yield curve. It is not clear, however, that any of these actions would be appropriate to achieve the legally mandated objectives of these central banks, particularly in an unusual crisis in which a certain amount of economic inactivity is desired for public health purposes.

\section{NOTES}

1 Brinca, Duarte, and Faria-e-Castro (2020) break sectoral shocks down into supply and demand shocks, finding that about two-thirds of the negative shocks were due to supply factors. Guerrieri et al. (2020) develop a theory of Keynesian supply shocks, that is, supply shocks that trigger larger changes in aggregate demand.

2 See IMF (2020d). For up-to-date information on policy responses of governments around the world to the COVID-19 crisis, see IMF (2020c).

$\underline{3}$ The Bank for International Settlements (2020) lists central bank policy rates. Not all central banks influence shortterm interest rates with open market operations. The ECB and many other central banks conduct policy by adjusting interest rates for lending to or borrowing from banks. In some countries, particularly emerging markets, the central bank conducts monetary policy by targeting the country's exchange rate rather than an interest rate.

4 The term "zero lower bound" was commonly used in the past to describe the zero level below which central banks did not push interest rates. As some central banks—not including the Fed—have pushed policy rates below zero, the term "effective lower bound" has become more commonly used. This term refers to the rate (usually negative) below which monetary policy cannot push interest rates or the rate below which such reductions are no longer stimulatory. The effective lower bound is likely to differ across countries.

$\underline{5}$ Forward guidance was not a new tool in 2008-09. For example, the Fed had been issuing statements after Federal Open Market Committee (FOMC) meetings since 1995. Similarly, the BOJ had used asset purchases in 2001-06. But central banks would use such methods on unprecedented scales and with much greater aggressiveness after 2008-09.

6 Central banks find it difficult to reduce short-term interest rates much below zero because lenders become increasingly reluctant to lend at negative interest rates when they could hold cash that pays a return of zero. The fact that holding large sums of cash is also costly has allowed some central banks_-for example, the ECB and BOJ-to reduce interest rates to modestly negative levels. Molyneux, Reghezza, and Xie (2019) argue that negative interest rates put pressure on the financial system's health, while many others find no evidence of this (Jobst and Lin, 2016; Basten and Mariathasan, 2018; Lopez, Rose, and Spiegel, 2020; and Arteta et al., 2016 and 2018).

7 See Ramey (2019).

8 The Term Auction Facility (TAF), introduced by the Fed in December 2007, allowed the Fed to loan money to banks for monetary policy purposes (see https://www.federalreserve.gov/monetarypolicy/taf.htm for details). The TAF sought to broadly increase bank credit rather than help particular banks as the discount window does.

9 Prior to the Dodd-Frank Act of 2010, the Fed could lend to individual financial institutions or firms under Federal Reserve Act Section 13(3) authority when the Fed's Board of Governors deemed circumstances to be "unusual and exigent." Lending to Bear Stearns and AIG in 2008 occurred under this authority but would not be allowed today. The shaded insert on the Dodd-Frank Act, "Did Post-2008 Financial Reforms Reduce Financial Crisis Risk?," describes the major changes in the U.S. regulatory structure. 


\section{Haas, Neely, Emmons}

10 The Fed is only one of many financial regulators, both federal and state, with overlapping responsibilities.

11 The BOE operated under a gold standard in the 19th century when Bagehot wrote. Bagehot advocated high interest rates during crises, to discourage excessive borrowing that would exhaust the BOE's gold reserves. Modern central banks can issue fiat currency, however, which allows them to create unlimited amounts of money. Therefore, there is less reason to be concerned about maintaining high lending rates.

12 Neely (2004) describes the Fed's lender-of-last-resort response to three crises: the stock market crash of 1987, the Russian default, and the September 11, 2001, terror attacks.

13 For a comparison of Fed actions in these two periods, see Wheelock (2010).

$\underline{14}$ Lacking good information about a particular firm's prospects or future profitability, lenders see a firm or individual's net worth as an important, quantifiable determinant of the ability to repay a loan.

15 A specialist is a member of a stock exchange who is obligated to make a market in a particular stock. That is, the specialist stands ready to buy or sell the asset. Ang, Gorovyy, and van Inwegen (2011) study hedge fund leverage.

16 Counterparty risk is the danger that one's counterparty will fail to settle a transaction.

17 The relationship between gross private domestic investment and U.S. recessionary periods can be seen here: https://fred.stlouisfed.org/graph/?g=r48w.

18 The secondary shocks likely to hit the economy and the financial system in the months to come still could trigger a financial crisis, however; see Bullard (2020).

19 The OECD data are available at https://data.oecd.org/gga/general-government-debt.htm.

$\underline{20}$ LIBOR is the London Interbank Offer Rate, applied to unsecured borrowing by a major bank from another bank. OIS is the Overnight Index Swap rate, referring to the fixed-rate leg of an interest rate swap against the overnight policy rate. In the United States, this is the federal funds rate. LIBOR is a default-risky rate and OIS is default-risk free rate because it effectively is secured by the other leg of the swap. Hence, the LIBOR-OIS spread is a clear indicator of perceived risk of default by a major bank.

$\underline{21}$ The USD did not appreciate during the period of the Russian default in August-November 1998.

$\underline{22}$ Financial crises and, to a lesser extent, recessions are very difficult to predict because if they could be predicted well in advance, people and firms would take actions_-such as selling risky assets or curtailing investment-that would bring them on immediately. The fourth quarter of 2019 was weak for Germany and Japan. An increase in the national sales tax weakened activity in Japan, and revised German GDP numbers showed a slight contraction (Fairless and Hannon, 2020, and Fujikawa, 2020).

$\underline{23}$ The OECD forecast (available at https://data.oecd.org/gdp/nominal-gdp-forecast.htm\#indicator-chart) annualized nominal second quarter GDP declines of 56 percent for the United Kingdom, 40 percent for the United States, 34 percent for Japan, and 48 percent for the euro area. An annualized decline in quarterly GDP of 25 percent, for example, means that second quarter GDP would be almost 7 percent lower than it would otherwise be: $0.75^{1 / 4} \approx 0.93=1-0.07$. If a 25 percent annualized drop in second quarter GDP is accompanied by no growth in each of the other quarters, total annual growth would be -7 percent.

24 In addition, the Fed's Board of Governors voted to lower the interest rate paid on reserves from 1.6 percent to 1.1 percent on March 3 and then to 0.1 percent on March 15.

$\underline{25}$ The ECB had already been engaged in asset purchases since November 2019. The BOJ was also already conducting asset purchases for years prior to the COVID-19 crisis.

$\underline{26}$ The recent trend toward greater investment by ETFs in corporate bonds is also of concern because this might amplify and transmit price moves through the economy. The BOE wrote about the issue in its July 2019 Financial Stability Report (BOE, 2019a, p. 35): "[L]arge-scale redemptions from funds could result in sales of illiquid assets that may exceed the ability of dealers and other investors to absorb them, amplifying price moves, transmitting stress to other parts of the financial system, and disrupting the availability of finance to the real economy."

$\underline{27}$ The ESF was established decades ago to allow the Treasury to intervene in foreign exchange markets.

28 More than 90 percent of MBS trading occurs in the TBA market, which is a forward market for agency MBS (Vickery and Wright, 2013). 
$\underline{29}$ ABS are structured securities that deliver coupon and principal payments from the repayment of one of many types of receivables, such as credit card loans, auto loans, or student loans. That is, lenders sell the rights to receive loan (or other) payments in the form of a bond (Agarwal et al., 2010). ABS are not government guaranteed, but they greatly broaden the market for small loans by transforming relatively risky, heterogeneous, low-value assets into safer, homogeneous fixed-income securities that can be sold to savers such as people or pension funds. This securitization increases the availability of loans and decreases borrowing costs. The Securities Industry and Financial Markets Association estimates that ABS issuance peaked in 2007 at \$796 billion (see https://www.sifma.org/ resources/research/fixed-income-chart/). The current version of the TALF had a similar predecessor during the GFC of 2007-09. The first version of the TALF began operating in March 2009, with outstanding loans peaking at just under $\$ 50$ billion in 2010. Almost all loans were repaid by the end of 2012.

30 The TALF is one of several credit facilities that the Fed reincarnated from the GFC of 2007-09, including the PDCF, the CPFF, and the MMLF. The Municipal Liquidity Facility (MLF), PPPLF, PMCCF and SMCCF, and the MSLP are the relevant new programs.

31 Foreign exchange swaps combine spot and forward transactions. When the Fed lends money through a swap, it sells USD to a foreign central bank and simultaneously contacts to buy those USD back at a specified time in the future for a specified price, which reflects the difference in interest rates on the currencies. Currency swaps entail minimal risk because the swapped currency functions as collateral.

A repo is secured borrowing in which one party purchases an asset and simultaneously sells it forward for a specified price. When the Fed lends money through a repo, it buys an asset from a foreign monetary authority and sells it back through a forward transaction. The difference between the forward and spot prices is the borrowing cost, and the exchanged currency itself acts as collateral that minimizes the risk to the lender.

32 In the United States, the relevant standard is the current expected credit losses (CECL) methodology; elsewhere, it is the International Financial Reporting Standards (IFRS 9) expected credit loss model.

$\underline{33}$ A capital buffer is the amount of capital a bank has above the required regulatory minimum.

34 The BOE, ECB, and Fed have also all issued guidelines to banks that restrict buybacks, dividends, and/or bonuses.

$\underline{35}$ A money market fund is said to "break the buck" when its net asset value falls below $\$ 1$. In such a case, money market fund investors may lose principal.

36 See https://www.federalreserve.gov/monetarypolicy/mainstreetlending.htm for MSLP facility terms.

37 The Fed's PPPLF also incentivizes bank lending by providing funding for banks that originate PPP loans, taking those loans as collateral.

38 Mizrach and Neely (2020b) cite IMF data in reporting that USD-denominated assets make up 60.9 percent of foreign exchange reserves, while euro-denominated assets make up 20.5 percent.

$\underline{39}$ Central banks had increasingly turned to open-ended asset purchase programs after the Fed shifted to conditioning QE3 asset purchases on economic activity on December 12, 2012 (Fawley and Neely, 2013).

$\underline{40}$ The $\mathrm{BOJ}$ is also continuing with its yield-curve control policy, targeting its longer-term 10-year JGB yield to 0 percent.

\section{REFERENCES}

Agarwal, Sumit; Barrett, Jacqueline; Cun, Crystal and De Nardi, Mariacristina. "The Asset-Backed Securities Markets, the Crisis, and TALF." Economic Perspectives, 2010, 34(4).

Altavilla, Carlo; Carboni, Giacomo and Motto, Roberto. "Asset Purchase Programmes and Financial Markets: Lessons from the Euro Area." Working Paper 1864, European Central Bank, November 2015.

Andrés, Javier; López-Salido, J. David and Nelson, Edward. “Tobin's Imperfect Asset Substitution in Optimizing General Equilibrium." Journal of Money, Credit and Banking, 2004, 36(4), pp. 665-90;

https://doi.org/10.1353/mcb.2004.0061.

Ang, Andrew; Gorovyy, Sergiy and van Inwegen, Gregory B. "Hedge Fund Leverage." Journal of Financial Economics, 2011, 102(1), pp. 102-26; https://doi.org/10.1016/j.jfineco.2011.02.020. 


\section{Haas, Neely, Emmons}

Arteta, Carlos; Kose, M. Ayhan; Stoker, Marc and Taskin, Temel. "Negative Interest Rate Policies: Sources and Implications." Working Paper 52/2016, Centre for Applied Macroeconomic Analysis, 2016; https://doi.org/10.1596/1813-9450-7791.

Arteta, Carlos; Kose, M. Ayhan; Stoker, Marc and Taskin, Temel. "Implications of Negative Interest Rate Policies: An Early Assessment." Pacific Economic Review, 2018, 23(1), pp. 8-26; https://doi.org/10.1111/1468-0106.12249.

Bagehot, Walter. Lombard Street. Simon and Schuster, 1873.

Bailey, Andrew. "Letter from the Governor to the Chancellor." March 17, 2020a; https://www.bankofengland.co.uk/-/media/boe/files/letter/2020/letter-from-the-governor-to-the-chancellormarch-2020.pdf?la=en\&hash=31274FBF31E982B78F8793A8DBBC98707C9FE251.

Bailey, Andrew. "Letter from the Governor to the Chancellor." March 19, 2020b; https://www.bankofengland.co.uk/-/media/boe/files/letter/2020/governor-letter-apf-march-2020. pdf?la=en\&hash=0C633B497A48C6D859300DAD7B2FB94BF0B9A263.

Bank for International Settlements. "Central Bank Policy Rates." 2020; https://www.bis.org/statistics/cbpol.htm.

Bank of England. "Financial Stability Report." Financial Policy Committee, July 2019; https://www.bankofengland.co.uk/-/media/boe/files/financial-stability-report/2019/july-2019.pdf.

Bank of England. "Bank of England Announces Supervisory and Prudential Policy Measures to Address the Challenges of Covid-19." March 20, 2020c; https://www.bankofengland.co.uk/news/2020/march/boe-announces-supervisory-and-prudential-policy-measures-to-address-the-challenges-of-covid-19.

Bank of England. "Bank of England Measures to Respond to the Economic Shock from Covid-19." March 11, 2020b; https://www.bankofengland.co.uk/news/2020/march/boe-measures-to-respond-to-the-economic-shock-fromcovid-19.

Basten, Christoph and Mariathasan, Mike. "How Banks Respond to Negative Interest Rates: Evidence from the Swiss Exemption Threshold." Working Paper 6901, CESifo, 2018.

BBC. "Coronavirus: The World in Lockdown in Maps and Charts." April 7, 2020; https://www.bbc.com/news/world-52103747.

Bernanke, Ben S. "Federal Reserve's Exit Strategy." Testimony before the Committee on Financial Services, U.S. House of Representatives, February 10, 2010; https://www.federalreserve.gov/newsevents/testimony/bernanke20100210a.htm.

Bernanke, Ben S. "Lecture 1: Origins and Mission of the Federal Reserve." Presented at The Federal Reserve and the Financial Crisis lecture series at George Washington University, March 20, 2012a; https://www.federalreserve.gov/aboutthefed/educational-tools/lecture-series-origins-and-mission.htm.

Bernanke, Ben S. "Lecture 3: The Federal Reserve's Response to the Financial Crisis." Presented at The Federal Reserve and the Financial Crisis lecture series at George Washington University, March 27, 2012b; https://www.federalreserve.gov/aboutthefed/educational-tools/lecture-series-federal-reserve-response-to-the-financial-crisis.htm.

Bernanke, Ben S. "What Tools Does the Fed Have Left? Part 1: Negative Interest Rates." Brookings Institution, March 18, 2016; https://www.brookings.edu/blog/ben-bernanke/2016/03/18/what-tools-does-the-fed-haveleft-part-1-negative-interest-rates/.

Bernanke, Ben S. "The New Tools of Monetary Policy: American Economic Association Presidential Address." Brookings Institution, January 4, 2020; https://www.brookings.edu/wp-content/uploads/2019/12/Bernanke ASSA lecture.pdf.

Bernanke, Ben S. and Gertler, Mark. "Agency Costs, Net Worth, and Business Fluctuations." American Economic Review, March 1989, 79(1), pp. 14-31.

Bhattarai, Saroj; Eggertsson, Gauti B. and Gafarov, Bulat. "Time Consistency and the Duration of Government Debt: A Signaling Theory of Quantitative Easing." NBER Working Paper 21336, National Bureau of Economic Research, 2015; https://doi.org/10.3386/w21336.

Bhattarai, Saroj; Eggertsson, Gauti B. and Gafarov, Bulat. "Time Consistency and Duration of Government Debt: A Model of Quantitative Easing." Working paper, 2019. 
Bhattarai, Saroj and Neely, Christopher J. "An Analysis of the Literature on International Unconventional Monetary Policy." Journal of Economic Literature (forthcoming).

Board of Governors of the Federal Reserve System. "Minutes of the Federal Open Market Committee, June 21-22, 2011." July 12, 2011; https://www.federalreserve.gov/monetarypolicy/fomcminutes20110622.htm.

Board of Governors of the Federal Reserve System. "Federal Reserve Issues FOMC Statement on Policy Normalization Principles and Plans." September 17, 2014;

https://www.federalreserve.gov/newsevents/pressreleases/monetary20140917c.htm.

Board of Governors of the Federal Reserve System. "FOMC Communications Related to Policy Normalization." October 11, 2019a; https://www.federalreserve.gov/monetarypolicy/policy-normalization.htm.

Board of Governors of the Federal Reserve System. "Report on the Economic Well-Being of U.S. Households in 2018." May 2019b;

https://www.federalreserve.gov/publications/files/2018-report-economic-well-being-us-households-201905.pdf.

Board of Governors of the Federal Reserve System. "Federal Reserve Supervision and Regulation Report - May 2020." May 2020a; https://www.federalreserve.gov/publications/2020-may-supervision-and-regulation-report.htm.

Board of Governors of the Federal Reserve System. "Factors Affecting Reserve Balances - H.4.1." June 25, 2020a; https://www.federalreserve.gov/releases/h41/20200625/.

Board of Governors of the Federal Reserve System. "Federal Reserve Board Releases Results of Stress Tests for 2020 and Additional Sensitivity Analyses Conducted in Light of the Coronavirus Event." June 25, 2020b; https://www.federalreserve.gov/newsevents/pressreleases/bcreg20200625c.htm.

Brinca, Pedro; Duarte, Joao B. and Faria-e-Castro, Miguel. "Measuring Sectoral Supply and Demand Shocks during COVID-19." Working Paper 2020-011B, Federal Reserve Bank of St. Louis, 2020; https://research.stlouisfed.org/wp/more/2020-011.

Brunnermeier, Markus K. and Koby, Yann. “The Reversal Interest Rate." NBER Working Paper 25406, National Bureau of Economic Research, 2018; https://doi.org/10.3386/w25406.

Bullard, James. "Three Lessons for Monetary Policy from the Panic of 2008." Federal Reserve Bank of St. Louis Review, May/June 2010, 92(3), pp. 155-63; https://doi.org/10.20955/r.92.155-164.

Bullard, James. "Fed's Bullard Says Risk of Financial Crisis Remains." Financial Times, July 1, 2020; https://www.ft.com/content/04ee5988-7864-431a-95ff-f18388f29894.

Burke, Chris; Hilton, Spence; Judson, Ruth; Lewis, Kurt and Skeie, David. "Reducing the IOER Rate: An Analysis of Options." Federal Open Market Committee Note, August 5, 2010; https://www.federalreserve.gov/monetarypolicy/files/FOMC20100805memo05.pdf.

C-SPAN. "Monetary Policy and the Economy." Testimony by Federal Reserve Chair Janet Yellen before the House Financial Services Committee, Semi-Annual Monetary Policy Report to Congress, February 10, 2016, 54:00-54:12; https://www.c-span.org/video/?404386-1/federal-reserve-chair-janet-yellen-testimony-monetary-policy.

Caballero, Ricardo J.; Hoshi, Takeo and Kashyap, Anil K. "Zombie Lending and Depressed Restructuring in Japan." American Economic Review, 2008, 98(5), pp. 1943-77; https://doi.org/10.1257/aer.98.5.1943.

Calomiris, Charles W. and Hubbard, R. Glenn. "Firm Heterogeneity, Internal Finance, and 'Credit Rationing."” Economic Journal, March 1990, 100(399), pp. 90-104; https://doi.org/10.2307/2233596.

Corsetti, Giancarlo and Dedola, Luca. "The Mystery of the Printing Press: Monetary Policy and Self-Fulfilling Debt Crises." Journal of the European Economic Association, 2016, 14(6), pp. 1329-71; https://doi.org/10.1111/jeea.12184.

De Pooter, Michiel; Martin, Robert F. and Pruitt, Seth. "The Liquidity Effects of Official Bond Market Intervention." Journal of Financial and Quantitative Analysis, 2018, 53(1), pp. 243-68; https://doi.org/10.1017/S0022109017000898.

Douglas, Jason and Hirtenstein, Anna. "Coronavirus Prods the U.K. to Consider the Once-Unthinkable: Negative Rates." Wall Street Journal, June 1, 2020; https://www.wsj.com/articles/coronavirus-prods-the-u-k-to-considerthe-once-unthinkable-negative-rates-11591009489.

Dreyer, Mallory and Nygaard, Kaleb. "Bank of Japan Introduces New Facility to Support Bank Lending to Small and Medium-Sized Firms." Yale School of Management Program on Financial Stability, May 22, 2020; https://som.yale.edu/blog/bank-of-japan-introduces-new-facility-to-support-bank-lending-to-small-and-medium-sized-firms. 


\section{Haas, Neely, Emmons}

Editorial Board. "The Central Bank That Ate Japan." Wall Street Journal, April 27, 2020; https://www.wsj.com/articles/the-central-bank-that-ate-japan-11588026341.

European Central Bank. "Press Release," April 30, 2020; https://www.ecb.europa.eu/press/pr/date/2020/html/ecb.pr200430 fa46f38486.en.html.

Fairless, Tom and Hannon, Paul. "Germany Enters Recession but Fares Better Than Neighbors." Wall Street Journal, May 15, 2020; https://www.wsj.com/articles/germany-enters-recession-but-fares-better-than-neighbors-11589547264.

Fannie Mae. "Monthly Summary." June 2020; https://www.fanniemae.com/resources/file/ir/pdf/monthly-summary/063020.pdf.

Fawley, Brett W. and Neely, Christopher J. "Four Stories of Quantitative Easing." Federal Reserve Bank of St. Louis Review, 2013, 95(1), pp. 51-88; https://doi.org/10.20955/r.95.51-88.

Financial Services Agency. "Concrete Measures Taken by Financial Institutions in Response to the COVID-19 Infection." May 22, 2020; https://www.fsa.go.jp/en/ordinary/coronavirus202001/20200420concrete measures.pdf.

Franck, Thomas. "Hardest-Hit Industries: Nearly Half the Leisure and Hospitality Jobs Were Lost in April." CNBC, May 8, 2020; https://www.cnbc.com/2020/05/08/these-industries-suffered-the-biggest-job-losses-in-april-2020.html.

Freddie Mac. "Monthly Volume Summary." Freddie Mac, June 2020; http://www.freddiemac.com/investors/financials/pdf/0620mvs.pdf.

Fujikawa, Megumi. "Trillion Schmillion: Japan Isn't Even Trying to Hit Its Bond-Buying Target." Wall Street Journal, January 21, 2019; https://www.wsj.com/articles/numbers-game-for-the-bank-of-japan-80-trillion-means-about20-trillion-11548072005.

Fujikawa, Megumi. "Japan's Economy Fell Into Recession in First Quarter of 2020." Wall Street Journal, May 17, 2020; https://www.wsj.com/articles/japans-economy-falls-into-recession-in-first-quarter-of-2020-11589760760.

Greenwood, Robin, and Vayanos, Dimitri. "Price Pressure in the Government Bond Market." American Economic Review, 2010, 100(2), pp. 585-90; https://doi.org/10.1257/aer.100.2.585.

Guerrieri, Veronica; Lorenzoni, Guido; Straub, Ludwig and Werning, Iván. "Macroeconomic Implications of COVID-19: Can Negative Supply Shocks Cause Demand Shortages?" NBER Working Paper 26918, National Bureau of Economic Research, 2020; https://doi.org/10.2139/ssrn.3570096.

Haas, Jacob and Neely, Christopher J. "Central Bank Responses to COVID-19." Federal Reserve Bank of St. Louis Economic Synopses, 2020, No. 23; https://doi.org/10.20955/es.2020.23.

International Monetary Fund. "Global Financial Stability Overview: Markets in the Time of COVID-19" in Global Financial Stability Report. Chapter 1, April 2020a; https://www.imf.org/en/Publications/GFSR/Issues/2020/04/14/ global-financial-stability-report-april-2020\#Chapter1.

International Monetary Fund. "IMF DataMapper: Real GDP Growth." IMF World Economic Outlook, April 2020b; https://www.imf.org/external/datamapper/NGDP RPCH@WEO/OEMDC/ADVEC/WEOWORLD.

International Monetary Fund. "Policy Responses to COVID-19." 2020c; https://www.imf.org/en/Topics/imf-and-covid19/Policy-Responses-to-COVID-19.

International Monetary Fund. "World Economic Outlook Update, June 2020." June 2020d; https://www.imf.org/en/Publications/WEO/Issues/2020/06/24/WEOUpdateJune2020.

Jobst, Andreas and Lin, Huidan. "Negative Interest Rate Policy (NIRP): Implications for Monetary Transmission and Bank Profitability in the Euro Area." Working Paper 2016/172, International Monetary Fund, 2016; https://doi.org/10.5089/9781475524475.001.

Karson, Evan, and Neely, Christopher J. "More Stories of Unconventional Monetary Policy." Federal Reserve Bank of St. Louis Review (forthcoming).

Kihara, Leika; Canepa, Francesco and Schneider, Howard. "Amid Rising Talk of Negative Rates, Policies in Japan, Europe Get Subtle Tweaks." Reuters, May 19, 2020; https://www.reuters.com/article/us-health-coronavirus-centralbanks-rates/amid-rising-talk-of-negative-rates-policies-in-japan-europe-get-subtle-tweaks-idUSKBN22VOHP. 
Lee, Lisa and Davis, Michelle F. "America's Zombie Companies Are Multiplying and Fueling New Risks." Bloomberg, May 19, 2020; https://www.bloomberg.com/news/articles/2020-05-19/america-s-zombie-companies-are-multiplying-and-fueling-new-risks.

Lopez, Jose A.; Rose, Andrew K. and Spiegel, Mark M. "Why Have Negative Nominal Interest Rates Had Such a Small Effect on Bank Performance? Cross Country Evidence." European Economic Review 124, 103402, 2020; https://doi.org/10.1016/j.euroecorev.2020.103402.

Ma, Alexandra. "The WHO Changed Its Coronavirus Timeline to Say It Got its First Report about the Virus on the Internet, Not from Chinese Authorities." Business Insider, July 5, 2020; https://www.businessinsider.com/who-changes-timeline-first-coronavirus-report-from-internet-china-2020-7.

Miller, Marcus; Weller, Paul and Zhang, Lei. "Moral Hazard and the US Stock Market: Analysing the 'Greenspan Put."' Economic Journal, 2002, 112(478), pp. C171-C186; https://doi.org/10.1111/1468-0297.00029.

Mizrach, Bruce and Neely, Christopher J. "Fed Intervention in the To-Be-Announced Market for Mortgage-Backed Securities." Federal Reserve Bank of St. Louis Economic Synopses, 2020a, No. 19; https://doi.org/10.20955/es.2020.19.

Mizrach, Bruce and Neely, Christopher J. "Federal Reserve System International Facilities." Federal Reserve Bank of St. Louis Economic Synopses, 2020b, No. 29; https://doi.org/10.20955/es.2020.29.

Mizrach, Bruce and Neely, Christopher J. “The Stock Market's Wild Ride." Federal Reserve Bank of St. Louis Economic Synopses, 2020c, No. 15; https://doi.org/10.20955/es.2020.15.

Mizrach, Bruce and Neely, Christopher J. "Secondary Market Corporate Credit Facility Supports Main Street." Federal Reserve Bank of St. Louis Economic Synopses, 2020d, No. 17; https://doi.org/10.20955/es.2020.17.

Mizrach, Bruce and Neely, Christopher J. "Supporting Small Borrowers: ABS Markets and the TALF." Federal Reserve Bank of St. Louis Economic Synopses, 2020e, No. 20; https://doi.org/10.20955/es.2020.20.

Molyneux, Philip; Reghezza, Alessio and Xie, Ru. "Bank Margins and Profits in a World of Negative Rates." Journal of Banking and Finance, 2019, 107, 105613; https://doi.org/10.1016/j.jbankfin.2019.105613.

National Bureau of Economic Research. "Determination of the February 2020 Peak in US Economic Activity." National Bureau of Economic Research Business Cycle Dating Committee, June 8, 2020;

https://www.nber.org/cycles/june2020.html.

Neely, Christopher J. “The Federal Reserve Responds to Crises: September 11th Was Not the First." Federal Reserve Bank of St. Louis Review, March/April 2004, 86(2), pp. 27-42; https://doi.org/10.20955/r.86.27-42.

Neely, Christopher J. "Lessons from the Taper Tantrum." Federal Reserve Bank of St. Louis Economic Synopses, 2014, No. 2; https://doi.org/10.20955/es.2014.2.

Neely, Christopher J. "Negative U.S. Interest Rates?" Federal Reserve Bank of St. Louis Economic Synopses, 2020, No. 4; https://doi.org/10.20955/es.2020.4.

Obama, Barack. "Barack Obama Speaks at the Cooper Union." Speech at the Cooper Union Dialogue Series, March 27, 2008, 17:30-22:00; https://cooper.edu/about/printed-publications/summer-2008/barack-obama.

Pasquariello, Paolo; Roush, Jennifer and Vega, Clara. "Government Intervention and Strategic Trading in the U.S. Treasury Market." Journal of Financial and Quantitative Analysis, 2020, 55(1), pp. 117-57; https://doi.org/10.1017/S0022109018001552.

Powell, Jerome H. "Coronavirus and CARES Act." Testimony before the Committee on Banking, Housing, and Urban Affairs, U.S. Senate, May 19, 2020a; https://www.federalreserve.gov/newsevents/testimony/powell20200519a.htm.

Powell, Jerome H. "Fed Chair Jerome Powell's 60 Minutes Interview on Economic Recovery from the Coronavirus Pandemic." Interview with Scott Pelley, CBS News/60 Minutes, May 13, 2020b; https://www.cbsnews.com/news/ full-transcript-fed-chair-jerome-powell-60-minutes-interview-economic-recovery-from-coronavirus-pandemic/.

Ramey, Valerie A. "Ten Years after the Financial Crisis: What Have We Learned from the Renaissance in Fiscal Research?" Journal of Economic Perspectives, 2019, 33(2), pp. 89-114; https://doi.org/10.1257/jep.33.2.89.

Reinhart, Carmen M. and Rogoff, Kenneth S. This Time is Different: Eight Centuries of Financial Folly. Princeton University Press, 2009; https://doi.org/10.1515/9781400831722. 


\section{Haas, Neely, Emmons}

Sano, Hideyuki and Kaneko, Kaori. "Japan Central Bank Loses Billions on ETFs, May Face Annual Loss." Reuters, March 23, 2020; https://www.reuters.com/article/us-japan-economy-boj/japan-central-bank-loses-billions-onetfs-may-face-annual-loss-idUSKBN21B0CX.

Schularick, Moritz and Taylor, Alan M. "Credit Booms Gone Bust: Monetary Policy, Leverage Cycles, and Financial Crises, 1870-2008." American Economic Review, 2012, 102(2), pp. 1029-61; https://doi.org/10.1257/aer.102.2.1029.

Schnabel, Isabel. "The ECB's Response to the COVID-19 Pandemic." Remarks at the webinar "The COVID-19 Crisis and Its Aftermath: Corporate Governance Implications and Policy Challenges," Frankfurt am Main, April 16, 2020; https://www.ecb.europa.eu/press/key/date/2020/html/ecb.sp200416 4d6bd9b9c0.en.html.

Skolimowski, Piotr. "Lane Says ECB Is Monitoring Markets, Ready to Boost Buying." Bloomberg, May 19, 2020; https://www.bloomberg.com/news/articles/2020-05-19/lane-says-ecb-is-monitoring-markets-ready-to-boostbond-buying.

Taylor, Derrick Bryson. "A Timeline of the Coronavirus Pandemic." New York Times, July 15, 2020; https://www.nytimes.com/article/coronavirus-timeline.html.

Timiraos, Nick. "Fed's Jerome Powell Says Economy Faces Long, Uncertain Recovery." Wall Street Journal, May 17, 2020; https://www.wsj.com/articles/feds-powell-says-economy-faces-long-uncertain-recovery-11589734446.

Timiraos, Nick and Hilsenrath, Jon. "The Federal Reserve Is Changing What It Means to Be a Central Bank." Wall Street Journal, April 27, 2020; https://www.wsj.com/articles/fate-and-history-the-fed-tosses-the-rules-to-fightcoronavirus-downturn-11587999986.

Tobin, James. "Liquidity Preference as Behavior Towards Risk." Review of Economic Studies, 1958, 25(2), pp. 65-86; https://doi.org/10.2307/2296205.

Tobin, James. "A General Equilibrium Approach to Monetary Theory." Journal of Money, Credit, and Banking, 1969, 1(1), pp. 15-29; https://doi.org/10.2307/1991374.

Trichet, Jean-Claude. "The ECB's Exit Strategy." Speech at the ECB Watchers Conference, Frankfurt, September 4, 2009; https://www.ecb.europa.eu/press/key/date/2009/html/sp090904.en.html.

U.S. Department of the Treasury. “Debt Position and Activity Report." TreasuryDirect, June 30, 2020; https://www.treasurydirect.gov/govt/reports/pd/pd debtposactrpt_0620.pdf.

Vayanos, Dimitri, and Vila, Jean-Luc. "A Preferred-Habitat Model of the Term Structure of Interest Rates." NBER Working Paper 15487, National Bureau of Economic Research, 2009; https://doi.org/10.3386/w15487.

Vickery, James and Wright, Joshua. "TBA Trading and Liquidity in the Agency MBS Market." Federal Reserve Bank of New York Economic Policy Review, 2013, 19(1), pp. 1-18; https://www.newyorkfed.org/medialibrary/media/research/epr/2013/1212vick.pdf.

Waller, Christopher. "Negative Interest Rates: A Tax in Sheep's Clothing." Federal Reserve Bank of St. Louis On the Economy Blog, May 2, 2016; https://www.stlouisfed.org/on-the-economy/2016/may/negative-interest-rates-tax-sheep-clothing.

Wheelock, David C. "Lessons Learned? Comparing the Federal Reserve's Responses to the Crises of 1929-33 and 2007-2009." Federal Reserve Bank of St. Louis Review, March/April 2010, 92(2), pp. 89-107; https://doi.org/10.20955/r.92.89-108.

World Health Organization. "Novel Coronavirus (2019-nCoV) Situation Report - 11." January 31, 2020a; https://www.who.int/docs/default-source/coronaviruse/situation-reports/20200131-sitrep-11-ncov.pdf?sfvrsn=de7c0f7 4.

World Health Organization. "Coronavirus Disease 2019 (COVID-19) Situation Report - 71." March 31, 2020b; https://www.who.int/docs/default-source/coronaviruse/situation-reports/20200331-sitrep-71-covid-19.pdf?sfvrsn=4360e92b 8.

World Health Organization. "WHO Coronavirus Disease (COVID-19) Dashboard." 2020c; https://covid19.who.int/, accessed July 2, 2020. 